\title{
Patient-derived mutations impact pathogenicity of SARS-CoV-2
}

2 Hangping $\mathrm{Yao}^{1} \uparrow$, Xiangyun $\mathrm{Lu}^{1} \uparrow$, Qiong $\mathrm{Chen}^{2} \uparrow$, Kaijin $\mathrm{Xu}^{1}$, Yu Chen ${ }^{1}$, Linfang Cheng ${ }^{1}$,

3 Fumin $\mathrm{Liu}^{1}$, Zhigang $\mathrm{Wu}^{1}$, Haibo $\mathrm{Wu}^{1}$, Changzhong $\mathrm{Jin}^{1}$, Min $\mathrm{Zheng}{ }^{1 *}$, Nanping $\mathrm{Wu}^{1 *}$,

4 Chao Jiang $2,3 *$, Lanjuan $\mathrm{Li}^{1 *}$

6 'State Key Laboratory for Diagnosis and Treatment of Infectious Diseases, National

7 Clinical Research Center for Infectious Diseases, First Affiliated Hospital, Zhejiang

8 University School of Medicine, Hangzhou, China.

$9 \quad{ }^{2}$ Life Sciences Institute, Zhejiang University, Hangzhou, China.

$10{ }^{3}$ Zhejiang Provincial Key Laboratory of Pancreatic Disease, First Affiliated Hospital,

11 Zhejiang University School of Medicine, Hangzhou, China.

$12 \dagger$ Equal contributions.

13 *Corresponding authors: M.Z. (minzheng@zju.edu.cn), N.W. (flwnp2013@163.com),

14 C.J. (jiang_chao@zju.edu.cn), and L.L. (1jli@zju.edu.cn). 
18 Summary (130 words)

19 The sudden outbreak of the severe acute respiratory syndrome-coronavirus

20 (SARS-CoV-2) has spread globally with more than 1,300,000 patients diagnosed and a

21 death toll of 70,000. Current genomic survey data suggest that single nucleotide variants

22 (SNVs) are abundant. However, no mutation has been directly linked with functional

23 changes in viral pathogenicity. We report functional characterizations of 11

24 patient-derived viral isolates. We observed diverse mutations in these viral isolates,

25 including 6 different mutations in the spike glycoprotein (S protein), and 2 of which are

26 different SNVs that led to the same missense mutation. Importantly, these viral isolates

27 show significant variation in cytopathic effects and viral load, up to 270-fold differences,

28 when infecting Vero-E6 cells. Therefore, we provide direct evidence that the

29 SARS-CoV-2 has acquired mutations capable of substantially changing its pathogenicity.

\section{$31 \quad$ Introduction}

32 Severe acute respiratory syndrome coronavirus 2 (SARS-CoV-2; previously referred to as

33 2019-nCoV), associated with the ongoing outbreak of atypical pneumonia, has already

34 caused a global pandemic beginning in Wuhan, Central China, despite China's extensive 
medRxiv preprint doi: https://doi.org/10.1101/2020.04.14.20060160; this version posted April 23, 2020. The copyright holder for this preprint (which was not certified by peer review) is the author/funder, who has granted medRxiv a license to display the preprint in perpetuity.

All rights reserved. No reuse allowed without permission.

35 systematic effort to contain the outbreak. As of April 7, 2020, SARS-CoV-2 has infected

36

37

38

39

40

41

42

43

44

45

46

47

48

more than 1.3 million people around the world with a death toll of 70,000 . The numbers

are still increasing rapidly. The estimate of the incubation period of SARS-CoV-2 (mean,

5.1 days; range, 4.5 to 5.8 days) (Lauer et al., 2020) is in line with those of other known

human coronaviruses, such as SARS (mean, 5 days; range, 2 to 14 days) (Varia et al.,

2003) and MERS (mean, 5 to 7 days; range, 2 to 14 days) (Virlogeux et al., 2016). The

reproductive number of SARS-CoV-2 is likely to be from 1.4 to 6.5 , with a mean of 3.3

(Liu et al., 2020), which is slightly higher than SARS, i.e., 2-5 (Bauch et al., 2005;

Lipsitch et al., 2003) and MERS, i.e., 2.7-3.9 (Lin et al., 2018). More than half of patients

with SARS-CoV-2 showed no signs of fever before hospitalization (Guan et al., 2020).

Strikingly, Coronavirus Diease-2019 (COVID-19) can be transmitted by asymptomatic

patients, who show no fever, gastrointestinal or respiratory symptoms, and have normal

chest computed tomography (Bai et al., 2020; Hu et al., 2020), making it much more

challenging to prevent the spread of COVID-19. Moreover, SARS-CoV-2 can remain

viable and infectious in aerosols for multiple hours and up to 7 days on surfaces (van

Doremalen et al., 2020). Although multiple in vitro studies or clinical trials on inhibitors

or drugs were carried out, no effective cures or vaccines have been found so far (Cao et 
medRxiv preprint doi: https://doi.org/10.1101/2020.04.14.20060160; this version posted April 23, 2020. The copyright holder for this preprint

(which was not certified by peer review) is the author/funder, who has granted medRxiv a license to display the preprint in perpetuity.

All rights reserved. No reuse allowed without permission.

52 al., 2020; Hoffmann et al., 2020; Wang et al., 2020). The World Health Organization

53 (WHO) declared COVID-19 a Public Health Emergency of International Concern on 30

54 January 2020, and raised the threat of the SARS-CoV-2 pandemic to the "very high"

55 level on February 28, 2020.

SARS-CoV-2 is the seventh member of enveloped RNA beta-coronavirus

57 (Sarbecovirus subgenus) (Zhu et al., 2020); SARS-CoV-2, SARS-CoV and MERS-CoV

58 can lead to devastating diseases, while HKU1, NL63, OC43 and 229E are related with

59 mild symptoms (Corman et al., 2018). So far, no recombination events were detected (Yu,

60 2020), although this could be at least partially due to the fact that most viral isolates were

61 sequenced with short-reads platform. The transmembrane spike (S) glycoprotein mediates

62 viral entry into host cells through homotrimers protruding from the viral surface. The S

63 protein includes two domains: S1 for binding to the host cell receptor and S2 for fusion of

64 the viral and cellular membranes, respectively (Tortorici and Veesler, 2019). Both

65 SARS-CoV-2 and SARS-CoV use the angiotensin converting enzyme 2 (ACE2) to enter

66 target cells (Walls et al., 2020). ACE2 is expressed in human nasal epithelial cells and

67 lung, spermatogonia, leydig, sertoli, gastric, duodenal, and rectal epithelial cells (Wang

and Xu, 2020; Xiao et al., 2020; Zhao et al., 2020). The receptor binding domain (RBD) 
medRxiv preprint doi: https://doi.org/10.1101/2020.04.14.20060160; this version posted April 23, 2020. The copyright holder for this preprint

(which was not certified by peer review) is the author/funder, who has granted medRxiv a license to display the preprint in perpetuity.

All rights reserved. No reuse allowed without permission.

69 in the S protein is the most variable genomic part in the betacoronavirus group (Wu et al.,

70 2020; Zhou et al., 2020), and some sites of S protein might be subjected to positive

71 selection (Lv et al., 2020). Despite the abundant variability of SARS-CoV-2, one key

72 question remains as to whether these mutations have any real functional impact on the

73 pathogenicity of SARS-CoV-2. This is crucial in our understanding of the viral infectious

74 mechanisms and dictates the strategy of drug and vaccine development in preparation for

75 the next stage of the pandemic.

76 To address this, we characterized 11 SARS-CoV-2 viral isolates from patients

77 admitted to Zhejiang University-affiliated hospitals in Hangzhou, China, situated 757

78 KMs to the east of Wuhan (see Materials and Methods). Super-deep sequencing of the 11

79 viral isolates on the Novaseq 6000 platform identified 1-5 mutations in the coding

80 sequences among the viral isolates. Mixed viral populations (representing quasi-species)

81 were also observed. We infected Vero-E6 cells with 11 viral isolates and quantitatively

82 assessed their viral load at 1, 2, 4, 8, 24, and 48 hours post infection (P.I.) and their viral

83 cytopathic effects (CPE) at 48 and 72 hours P.I.. Our results show that the observed

84 mutations can have a direct impact on the viral load and CPE when infecting Vero-E6

85 cells, as much as 270 -fold differences between the extremities. This finding suggests that 
medRxiv preprint doi: https://doi.org/10.1101/2020.04.14.20060160; this version posted April 23, 2020. The copyright holder for this preprint

(which was not certified by peer review) is the author/funder, who has granted medRxiv a license to display the preprint in perpetuity.

All rights reserved. No reuse allowed without permission.

86 the observed mutations in our study, and possibly in the viral isolates collected around

87 the world, can significantly impact the pathogenicity of SARS-CoV-2.

88

89 Results

90 Summary of the epidemiological history of the patients

91 The samples of the 11 patients involved in this study were collected during the early

92 phase of the COVID-19 breakout in China, dates ranging from $1 / 22 / 2020$ to $2 / 4 / 2020$

93 (Table 1). 10 of the 11 patients had clear connections with Wuhan city, where the

94 SARS-CoV-2 was originally identified. 5 of the 11 people either worked in or traveled to

95 Wuhan before they were diagnosed, and another 5 had close contact with people who

96 lived in Wuhan, and the remaining person had contact with people who were COVID-19

97 victims. Notably, patients ZJU-4, -5, -9 attended the same business conference where a

98 few colleagues from Wuhan were present. These patients therefore constitute 1 st and 2 nd

99 generations of the viral victims based on their epidemiological history. The 11 patients

100 include 8 males and 3 females, with ages ranging from 4 months to 71 years old. There

101 are no clear criteria in selecting these patients other than the fact that they were all

102 admitted into Zhejiang University-affiliated hospitals in Hangzhou. All except one of the 
medRxiv preprint doi: https://doi.org/10.1101/2020.04.14.20060160; this version posted April 23, 2020. The copyright holder for this preprint (which was not certified by peer review) is the author/funder, who has granted medRxiv a license to display the preprint in perpetuity. All rights reserved. No reuse allowed without permission.

103 patients had moderate or worse symptoms. 3 patients had co-morbidity conditions and

104 one patient needed ICU treatment. Luckily, all of the patients have recovered as of the

105 time of writing this article.

\begin{tabular}{|c|c|c|c|c|c|c|c|c|c|c|c|c|c|c|}
\hline ID & Sex & Age & Sample & $\begin{array}{c}\text { Sample } \\
\text { collection } \\
\text { date }\end{array}$ & $\begin{array}{c}\begin{array}{c}\text { Virus } \\
\text { isolating } \\
\text { date }\end{array} \\
\end{array}$ & $\begin{array}{l}\text { Epide- } \\
\text { miology }\end{array}$ & $\begin{array}{l}\text { Viral } \\
\text { gen }\end{array}$ & $\begin{array}{c}\text { Onset } \\
\text { sypmtoms }\end{array}$ & Severity & $\begin{array}{c}\text { Blood } \\
\text { presure }\end{array}$ & ICU & $\begin{array}{c}\text { Onset } \\
\text { date }\end{array}$ & Admission & Discharge \\
\hline ZJU_1 & M & 36 & Sputum & 1.25 & 1.29 & $\begin{array}{l}\text { Contact with } \\
\text { people from } \\
\text { Wuhan }\end{array}$ & 2 & Fever & Moderate & 0 & 0 & 1.23 & 1.25 & 2.23 \\
\hline ZJU_2 & M & 31 & Sputum & 1.26 & 1.29 & $\begin{array}{l}\text { Lived in } \\
\text { Wuhan }\end{array}$ & 1 & Fever & Severe & 0 & 0 & 1.23 & 1.24 & 2.23 \\
\hline ZJU_3 & M & 32 & Sputum & 1.25 & 1.30 & $\begin{array}{l}\text { Traveled to } \\
\text { Wuhan }\end{array}$ & 2 & Fever & Severe & 0 & 0 & 1.18 & 1.19 & 2.12 \\
\hline ZJU_4 & M & 34 & Sputum & 1.24 & 1.28 & 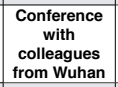 & 2 & $\begin{array}{l}\text { Fever, } \\
\text { fatigue }\end{array}$ & Moderate & 0 & 0 & 1.17 & 1.21 & 2.9 \\
\hline ZJU_5 & $\mathbf{F}$ & 25 & Sputum & 1.22 & 1.26 & $\begin{array}{c}\text { Conference } \\
\text { with } \\
\text { colleagues } \\
\text { from Wuhan }\end{array}$ & 2 & Fever & Severe & 0 & 0 & 1.21 & 1.22 & 2.9 \\
\hline ZJU_6 & M & 71 & Sputum & 2.2 & 2.6 & \begin{tabular}{|c|}
$\begin{array}{c}\text { Contact with } \\
\text { people who } \\
\text { had COVID19 } \\
\text { Wuhan. }\end{array}$ \\
\end{tabular} & 2 or 3 & $\begin{array}{l}\text { Fever, } \\
\text { fatigue }\end{array}$ & Severe & 1 & 0 & 1.22 & 1.26 & 2.19 \\
\hline ZJU_7 & $\mathbf{F}$ & $4 \mathrm{M}$ & $\begin{array}{c}\text { Nasopharyngeal } \\
\text { swab }\end{array}$ & 2.3 & 2.8 & $\begin{array}{c}\text { Contact with } \\
\text { people from } \\
\text { Wuhan }\end{array}$ & 2 & Fever & Mild & 0 & 0 & 1.29 & 1.29 & 2.20 \\
\hline ZJU_8 & M & 53 & Sputum & 1.26 & 1.30 & $\begin{array}{l}\text { Lived in } \\
\text { Wuhan }\end{array}$ & 1 & $\begin{array}{l}\text { Fever, } \\
\text { fatigue }\end{array}$ & Critical & 1 & 1 & 1.17 & 1.22 & 2.19 \\
\hline ZJU_9 & M & 30 & Stool & 1.28 & 2.7 & \begin{tabular}{|c|} 
Conference \\
with \\
colleagues \\
from Wuhan
\end{tabular} & 2 & Fever & Severe & 0 & 0 & 1.18 & 1.21 & 2.5 \\
\hline ZJU_10 & $F$ & 38 & Stool & 2.3 & 2.8 & $\begin{array}{l}\text { Lived in } \\
\text { Wuhan }\end{array}$ & 1 & Fever & Severe & 0 & 0 & 1.19 & 1.27 & 2.12 \\
\hline ZJU_11 & M & 62 & Stool & 2.4 & 2.9 & $\begin{array}{l}\text { Lived in } \\
\text { Wuhan }\end{array}$ & 1 & Coughing & Severe & 1 & 0 & 1.19 & 1.26 & 3.15 \\
\hline
\end{tabular}

107 Table 1. A summary of the epidemiological information of the 11 patients involved in

108 this study. The "Viral gen" (viral generation) was inferred based on their exposure

109 history.

112 To assess the mutational spectrum of these 11 viral isolates, ultra-deep sequencing of the

113 isolated viral genomic RNA was performed on the Illumina Novaseq 6000 platform, 
medRxiv preprint doi: https://doi.org/10.1101/2020.04.14.20060160; this version posted April 23, 2020. The copyright holder for this preprint (which was not certified by peer review) is the author/funder, who has granted medRxiv a license to display the preprint in perpetuity.

All rights reserved. No reuse allowed without permission.

114 generating on average 245 million post-cleaning reads/67.16 Gb per sample (Table S1;

115 average coverage exceeding $2,000,000 \mathrm{X}$ ). This extraordinary depth is partially due to the

116 small genome of the SARS-CoV-2, which enables us to identify mutations with high

117 confidence. Moreover, in cases where the viral populations are not homogenous, the

118 depth could help us to characterize alleles with very low frequency.

119 In total, 33 mutations were identified (including 10 mutations observed in

120 mixed-populations), and 19 of these mutations were novel, according to the comparison

121 with 1111 genomic sequences available at GISAID on 3/24/2020 (Fig. 1, S1, and S2).

122 Specifically, G11083T and G26144T were found in ZJU-1, and both of these mutations

123 are known as founding mutations for a large group of viruses (Capobianchi et al., 2020).

124 C8782T and T28144C were found in two of our viral isolates, ZJU-2 and ZJU-8, and

125 these two are known as the founding mutations for another large group of viral isolates

126 (Capobianchi et al., 2020). Interestingly, mutation T22303G was found in five viral

127 isolates (ZJU-2, -5, -9, -10, and -11) and ZJU-5 and ZJU-9 were exposed to the same

128 potential source of infection during a business conference (Table 1). Previously, only one

129 viral isolate identified in Australia had the T22303G mutation. Strikingly, the viral isolate

130 from patient ZJU-4, who attended the same conference as ZJU-5 and ZJU-9, has a novel 
medRxiv preprint doi: https://doi.org/10.1101/2020.04.14.20060160; this version posted April 23, 2020. The copyright holder for this preprint

(which was not certified by peer review) is the author/funder, who has granted medRxiv a license to display the preprint in perpetuity.

All rights reserved. No reuse allowed without permission.

131 mutation, A22301C, which causes the same missense mutation at the protein level

132 (S247R in the $\mathrm{S}$ protein) as $\mathrm{T} 22303 \mathrm{G}$, mutating the 1st instead of the 3rd position in the

133 respective codon. Observations of these two single nucleotide variants can only be

134 coincidental, albeit very unexpected. Finally, the ZJU-11 has 4 mutations in the ORF7b

135 gene, 3 of which are consecutive and introduce 2 mutations at the protein level.

136 Di-nucleotide and Tri-nucleotide mutations are of course rarer than SNV, but not

137 exponentially so, according to previous mutational accumulation studies in prokaryotes

138 (Lynch, 2007).

139 It is important to note that while the sequence data deposited in GISAID are very

140 helpful in tracking inter-personal variation of the virus, we still do not know much about

141 intra-personal viral evolutionary dynamics. For example, in ZJU-4 and ZJU-10, alleles of

142 two separate sites have very similar frequency distributions, indicating that these two

143 sites are probably linked, representing at least two haplotypes within the viral populations.

144 And as revealed by this study, 6 of the identified mutations would have been ignored if

145 using the consensus sequences for analyses. Taken together, despite only 11

146 patient-derived isolates being analyzed in this study, we observed abundant mutational

147 diversity, including several founding mutations for different major clusters of viruses 
medRxiv preprint doi: https://doi.org/10.1101/2020.04.14.20060160; this version posted April 23, 2020. The copyright holder for this preprint (which was not certified by peer review) is the author/funder, who has granted medRxiv a license to display the preprint in perpetuity. All rights reserved. No reuse allowed without permission.

148 now circulating globally. This diverse mutational spectrum is consistent with their

149 relatively early sampling time and relative proximity to Wuhan city, where the first viral

150 strain was identified. The full mutational diversity of the virus in Wuhan city in the early

151 days is still unknown to this day, due to limited sampling (Lu et al., 2020; Zhou et al.,

152 2020).
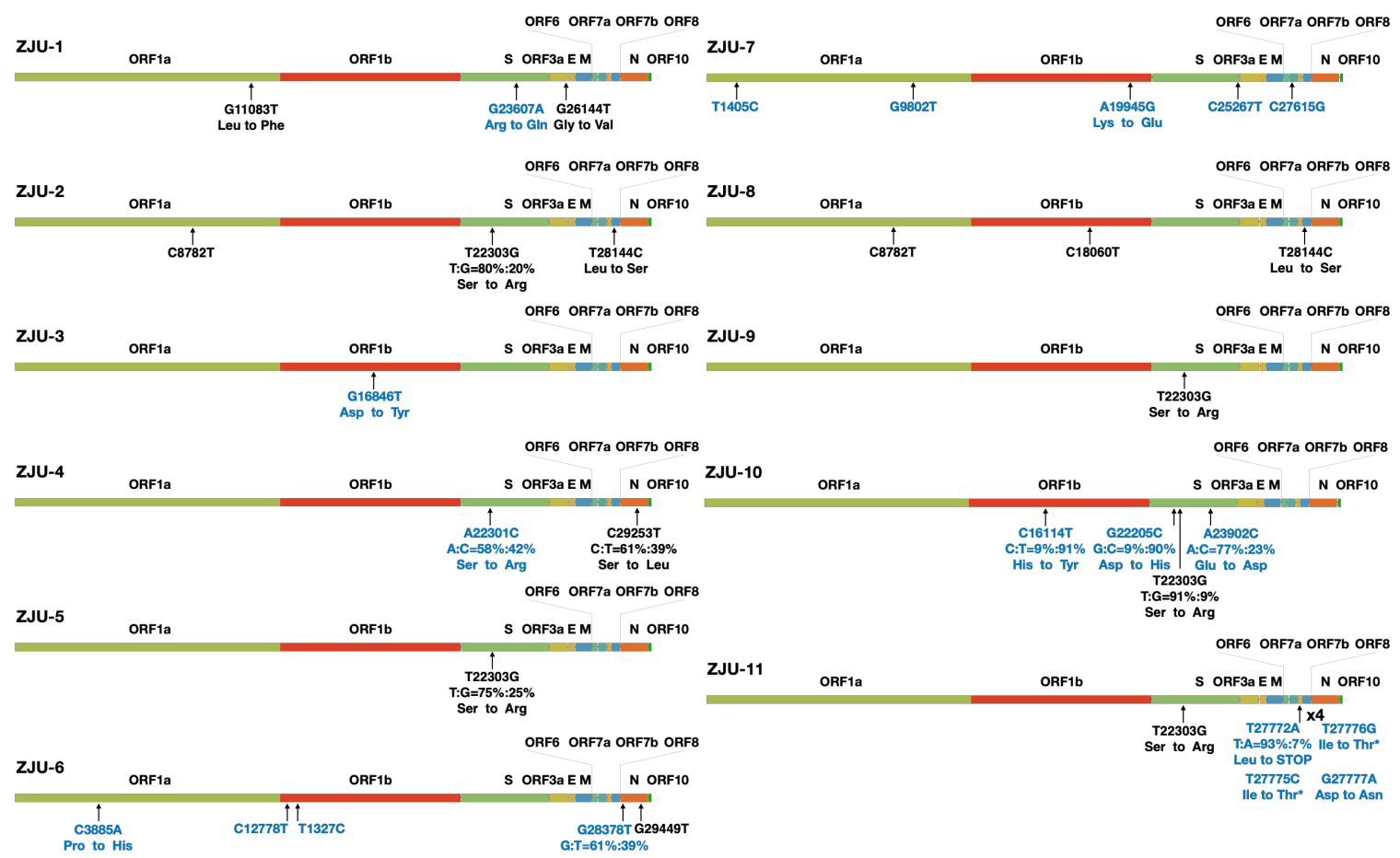

154 Fig. 1. A summary of the mutations identified in each of the 11 viral isolates. Each ORF

155 of the viral genome was denoted based on the annotations of NC_045512.2 as provided

156 by NCBI. If a mutation was observed in the context of a mixed population, the respective

157 percentages of the top two alleles are provided. Changes at the amino acid level are

158 provided if applicable. Blue color indicates novel mutation at the time of writing the 
159 article.

160

161 Phylogenetic analysis of the patient-derived viral isolates reveals their diverse

162 evolutionary history

163 To understand the phylogenetic context of 11 viral isolates with respect to the corpus of

164 available SARS-CoV-2 sequencing data, we acquired 725 high quality and high coverage

165 SARS-CoV-2 genomes from GISAID (downloaded on 3/21/2020), including the Yunnan

166 RaTG13 viral strain and the Guangdong pangolin viral strain as the outgroup. We aligned

167 the 736 genomic sequences with MAFFT (see Materials and Methods) and trimmed the

168 full-length alignment with trimAL (see Materials and Methods) to remove any spurious

169 parts of the alignment. We used iqtree (see Materials and Methods) to construct a

170 1000-times bootstrapped maximum-likelihood phylogenic tree of the 736 viral sequences

171 based on 835 parsimony informative sites (Fig. 2A). The resulting phylogenetic tree is

172 largely consistent with the phylogenetic analysis being updated on GISAID (Fig. S3). We

173 want to emphasize that due to the rapidly developing COVID-19 situation, tens or even

174 hundreds of new sequences are being uploaded to the GISAID every day. As a result,

175 new observations may be generated when more data are available. 
medRxiv preprint doi: https://doi.org/10.1101/2020.04.14.20060160; this version posted April 23, 2020. The copyright holder for this preprint (which was not certified by peer review) is the author/funder, who has granted medRxiv a license to display the preprint in perpetuity. All rights reserved. No reuse allowed without permission.

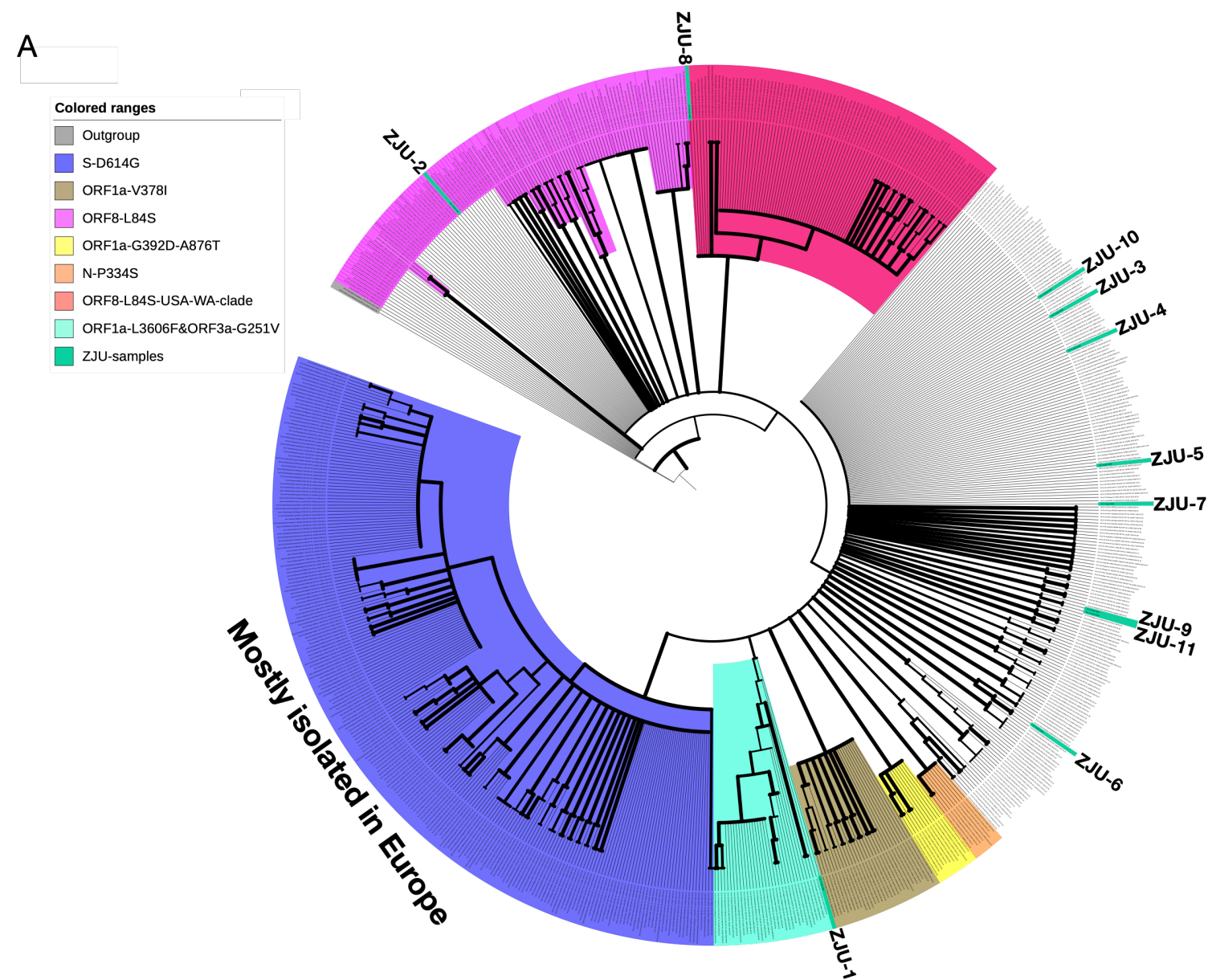

B
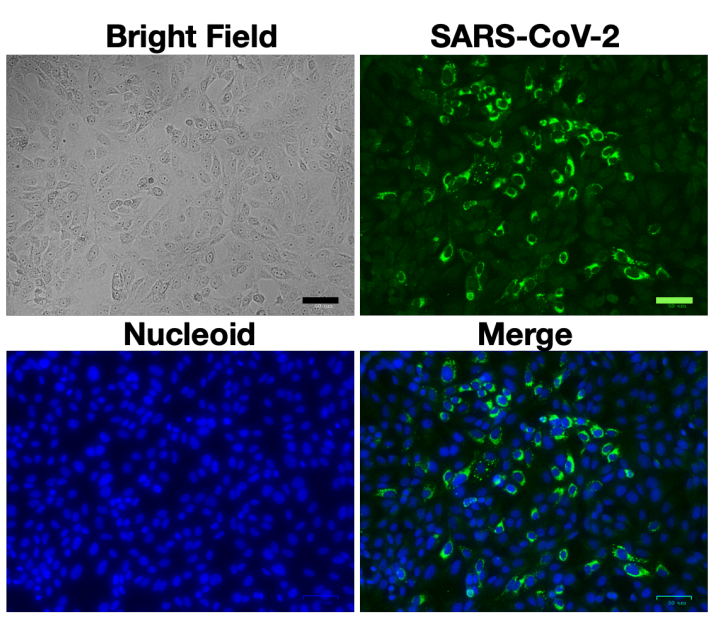

C

Fig. 2. Characterizations of the patient-derived SARS-CoV-2 isolates. (A) Phylogenetic

178 analyses of the 11 viral isolates in the context of 725 SARS-CoV-2 sequences 
medRxiv preprint doi: https://doi.org/10.1101/2020.04.14.20060160; this version posted April 23, 2020. The copyright holder for this preprint (which was not certified by peer review) is the author/funder, who has granted medRxiv a license to display the preprint in perpetuity.

All rights reserved. No reuse allowed without permission.

179 downloaded from GISAID. The 1000-times bootstrapped maximum likelihood tree was

180 constructed to demonstrate the phylogenetic context of the 11 viral isolates. Major and

181 minor clusters were color-coded and denoted as shown in the "colored ranges" inset box.

182 All ZJU- samples were color-codded as green. The width of a branch indicates bootstrap

183 supporting level. (B) Fluorescent labeling of the viral S protein indicates that isolated

184 SAR-CoV-2 viral particles (Green) bind to the peripherals of the Vero-E6 cells (DNA

185 stained as Blue) prior to entry. Scale bars, $50 \mu \mathrm{m}$. (C) A representative TEM picture of

186 the isolated SAR-CoV-2 viral particles, arrows indicate the iconic "crown" consisted of S

187 proteins (Spike). Scale bar, $100 \mathrm{~nm}$.

188

We observed quite a few sets of founding mutations. Specifically, we note the

190 following three biggest clusters in our phylogenetic analysis: 1. Three nucleotide

191 mutations C241T (silent), C14408T (silent), and A23403G (D614G in S) found a group

192 of 231 viral sequences (Fig. 2A; S-D614G cluster), most of which were isolated in

193 Europe; 2. Two nucleotide mutations C8782T (silent) and T28144C (L84S in ORF8),

194 found a group of 208 viral sequences (Fig. 2A; ORF8-L84S cluster), which is not 
medRxiv preprint doi: https://doi.org/10.1101/2020.04.14.20060160; this version posted April 23, 2020. The copyright holder for this preprint (which was not certified by peer review) is the author/funder, who has granted medRxiv a license to display the preprint in perpetuity.

All rights reserved. No reuse allowed without permission.

195 monophyletic in our analysis (Fig. 2A and S3). However, a distinct monophyletic

196 subclade of 92 sequences within the ORF8-L84S cluster can be observed, mainly

197 composed of viral sequences isolated from Seattle, USA (Fig. 2A;

198 ORF8-L84S-USA-WA-clade); 3. Two nucleotide mutations, G11083T (L3606F in

199 ORF1a), and G26144T (G251V in ORF3a) found a group of 34 viral sequences, most of

200 which were from Netherlands and England. Several smaller monophyletic clusters,

201 defined by different sets of founding mutations (bootstrap supporting value $>95$ ), can be

202 observed. For examples: 1. the G1937A (V378I in ORF1a) mutation founds a cluster of

20331 viral sequences; 2. the G1440A and G2891A mutations, resulting in G392D and

204 A876T mutations in the ORF1a gene, founds a cluster of 12 viral sequences, mostly from

205 Germany or Netherlands; 3. the C15325T and C29303T mutations, resulting in P344S

206 mutation in the $\mathrm{N}$ gene, founds a small cluster of 8 sequences, all of which are from

207 China or Japan. When integrating the characterized 11 viral isolates into the phylogenetic

208 analysis, they are dispersed across the entire phylogenetic space. ZJU-1 clusters with the

209 ORF1a-L3606F \& ORF3a-G251V groups, as it has both of the two defining mutations

210 (Fig. 2A). ZJU-2 and ZJU-8, on the other hand, cluster with the ORF8-L84S cluster

211 because they both have the two founding mutations (Fig. 2A). ZJU-9 and ZJU-11 cluster 
medRxiv preprint doi: https://doi.org/10.1101/2020.04.14.20060160; this version posted April 23, 2020. The copyright holder for this preprint

(which was not certified by peer review) is the author/funder, who has granted medRxiv a license to display the preprint in perpetuity.

All rights reserved. No reuse allowed without permission.

212 with an Australian isolate because of the aforementioned T22303G mutation. The rest of

213 the group either have few mutations or novel mutations that do not cluster with any

214 known sizable groups, reflecting the extensive diversity within our 11 samples. Taken

215 together, some monophyletic clusters of viruses do show obvious geographic patterns

216 (Europe and WA-USA especially), but this could be due to the founding effect of

217 respective mutations that happened early during the initial phase of the pandemic.

219 Patient-derived SARS-CoV-2 isolates show significant variation in viral copy

220 number and cytopathic effects when infecting Vero-E6 cells

221 There is much speculations and many theories behind the observed mutations in

222 sequenced viral isolates. Theoretically, one usually needs not often invoke selection

223 arguments in explaining the origin of these mutations, as the human to human infection

224 process is a series of repeated naturally-occurring bottlenecking events, in which the

225 seeding viral population can be as little as hundreds of viral copies (Forni et al., 2017).

226 Therefore, a significant portion of the genetic diversity or even population-specific

227 fixations could be due to this process, where selection plays a small role (Renzette et al.,

228 2017). We conducted Tajima's test of neutrality using the constructed alignment of viral 
medRxiv preprint doi: https://doi.org/10.1101/2020.04.14.20060160; this version posted April 23, 2020. The copyright holder for this preprint (which was not certified by peer review) is the author/funder, who has granted medRxiv a license to display the preprint in perpetuity.

All rights reserved. No reuse allowed without permission.

229 sequences and Taijima's D is -2.8874 with a nucleotide diversity $(\pi)$ of 0.000641 ( $\mathrm{p}<$

$230 \quad 0.05$ according to simulations performed in (Tajima, 1989), indicating that the

231 SARS-CoV-2 genome has an excess of low-frequency alleles due to recent population

232 expansions, consistent with the repeated bottlenecking events during viral infections.

233 However, certain mutations do provide selection advantages or disadvantages under

234 specific circumstances, as shown by the discovery that adaptive mutations are highly

235 enriched in the interface between the S protein and the human ACE2 receptor (Ou et al.,

236 2020).

237 To examine the mutational impact of the patient-derived SARS-CoV-2 isolates, we

238 conducted in vitro infectivity assay. We chose in vitro assay because COVID-19 patients

239 show a wide variety of clinical symptoms ranging from asymptotic to death, and

240 epidemiological research have shown that the clinical outcomes are heavily influenced by

241 individual's age, complications, and other potential unknown parameters (Guan et al.,

242 2020). We first examined whether the viral isolates could successfully bind to Vero-E6

243 cells as expected (Fig. 2B), and visually identified the viral particles with the iconic

244 "crown" formed by S proteins (Fig. 2C and S4A). We then infect the Vero-E6 cells with

245 all 11 patient-derived viral isolates and harvest the cells at 1, 2, 4, 8 (in quadruplicates), 
medRxiv preprint doi: https://doi.org/10.1101/2020.04.14.20060160; this version posted April 23, 2020. The copyright holder for this preprint (which was not certified by peer review) is the author/funder, who has granted medRxiv a license to display the preprint in perpetuity.

All rights reserved. No reuse allowed without permission.

246 24, and 48 (in duplicates) hours P.I. (see Materials and Methods); we included the

247 supernatant because cell death releases viral particles. DIC micrographs of the cells at 48

248 hours and 72 hours P.I. were also taken to assess the CPE. We used specific real-time

249 reverse transcriptase-polymerase chain reaction (RT-PCR) targeting ORF1a, E, and N

250 genes to detect the presence of SARS-CoV-2 (see Materials and Methods). Cycle

251 threshold values, $C_{t}$, were used to quantify the viral load, with lower values indicating

252 higher viral load. Because the results based on the three genes are highly consistent ( $\mathrm{R}>$

$2530.99, \mathrm{p}<2.2 \mathrm{e}-16$ ), we will only discuss the results of the ORF1a gene (Fig. 3A). We

254 failed to detect any significant signals from our negative controls, hence we simply

255 assigned a $\mathrm{C}_{\mathrm{t}}$ value of 40 for all them.

256 Briefly, the $C_{t}$ values of samples remained mostly flat with small fluctuations for all

257 of the viral isolates at 1, 2, and 4 hours P.I. (Fig. 3A and B). During these early hours,

258 viral particles are binding to gain access into the cells, and replications would rarely

259 occur (Schneider et al., 2012). At 8 hours P.I., we observed significant decreases in Ct

260 value (increases in viral load) for ZJU-6, ZJU-7, ZJU-9, ZJU-10, and ZJU-11. At 24

261 hours P.I., we observed significant decreases in $C_{t}$ values for all of the viral isolates

262 except for ZJU-2 and ZJU-7, although some of the viral isolates, namely ZJU-10 and 
medRxiv preprint doi: https://doi.org/10.1101/2020.04.14.20060160; this version posted April 23, 2020. The copyright holder for this preprint (which was not certified by peer review) is the author/funder, who has granted medRxiv a license to display the preprint in perpetuity.

All rights reserved. No reuse allowed without permission.

263 ZJU-11, decreased much faster than the others (Fig. 3A and B). At 48 hours P.I., we

264 observed small decreases for all viral isolates except for ZJU-10 and ZJU-11, both of

265 which had presumably already plateaued at 24 hours P.I. (Fig. 3A and B). Notably, at 24

266 hours P.I., ZJU-2 and ZJU-8, members of the ORF-8-L84S cluster (majority of USA

267 WA-Seattle isolates are in this group), showed considerably lower viral loads (Fig. 4A).

268 On the other hand, ZJU-1, which clusters with the S-D614G clade (mostly found in

269 Europe), has a viral load 19 times $\left(2^{4.25}\right)$ higher than ZJU-2 and ZJU-8 (Fig. 4A). In

270 addition, a near 270 -fold difference $\left(2^{8.09}\right)$ in viral load was observed between ZJU-10

271 and ZJU-2 at 24 hours P.I. (Fig. 4A). These differences became statistically significant at

27248 hours P.I., and are reproducible when analyzing data on gene E and N (Fig. S4B and C;

273 Fig. S5A). Therefore, different viral isolates, which are defined by different mutations in

274 their genomes, exhibit a significant variation of viral load when infecting Vero-E6 cells.

275 We next examined whether a higher viral load leads to more cell death (Fig. 4B).

276 When examining these cell lines under a microscope at 48 hours and 72 hours P.I., the

277 CPE, or the cell death rate, are highly consistent with the viral load data (Fig. 4C and S5B,

$278 \mathrm{C}$, and D; at 48 hours P.I., $\mathrm{C}_{\mathrm{t}}$ vs $\left.\mathrm{CPE}, \mathrm{R}=-0.72, \mathrm{p}=0.015\right)$, indicating that a higher viral

279 load leads to a higher cell death ratio. Note that the $C_{t}$ numbers are negatively correlated 
medRxiv preprint doi: https://doi.org/10.1101/2020.04.14.20060160; this version posted April 23, 2020. The copyright holder for this preprint (which was not certified by peer review) is the author/funder, who has granted medRxiv a license to display the preprint in perpetuity. All rights reserved. No reuse allowed without permission.

with the $\mathrm{CPE}$ because a lower $\mathrm{C}_{\mathrm{t}}$ number means a higher viral load.

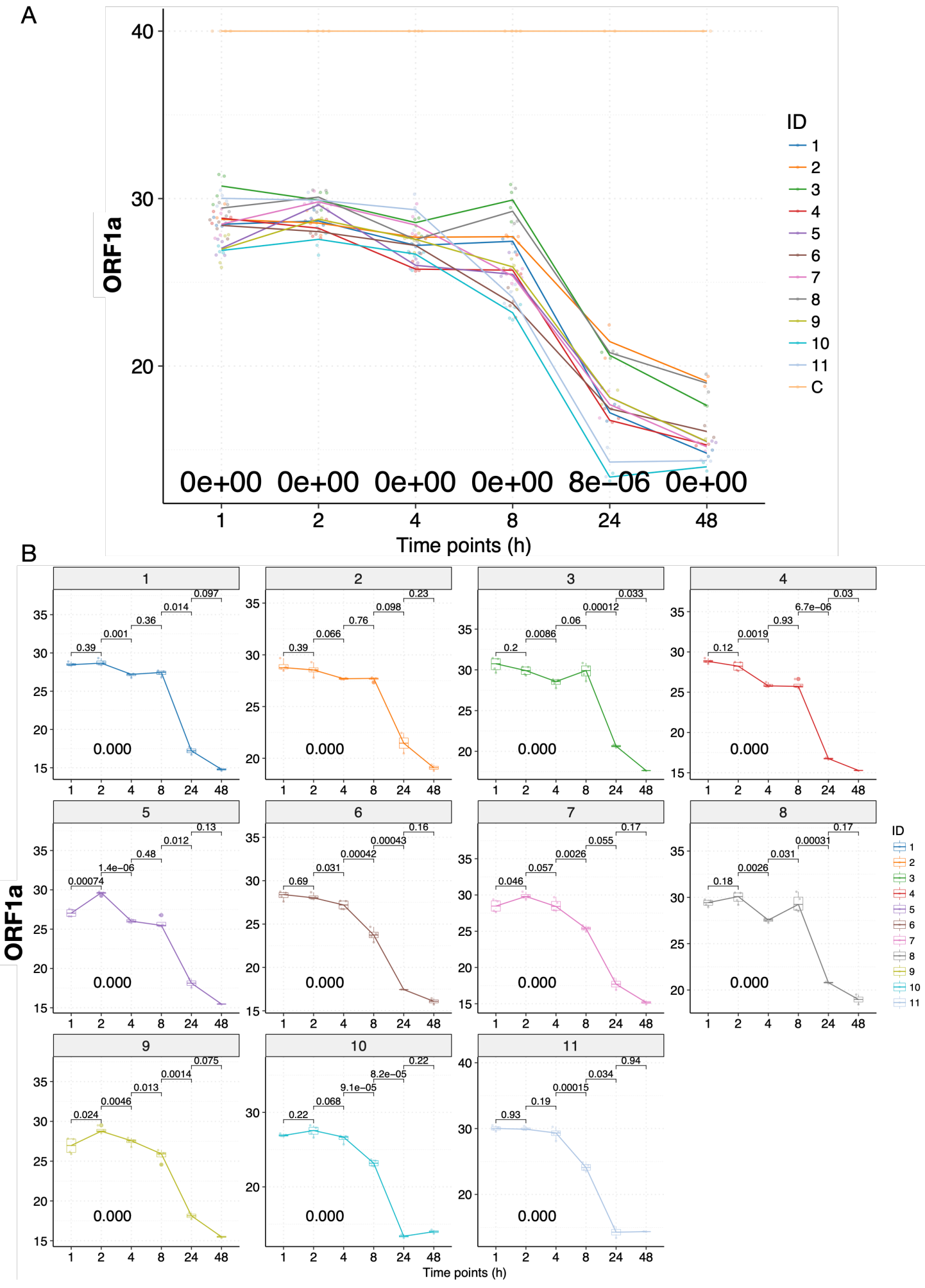


medRxiv preprint doi: https://doi.org/10.1101/2020.04.14.20060160; this version posted April 23, 2020. The copyright holder for this preprint

(which was not certified by peer review) is the author/funder, who has granted medRxiv a license to display the preprint in perpetuity.

All rights reserved. No reuse allowed without permission.

282 Fig. 3. The infectivity assay reveals temporal variation in the viral load of the

283 patient-derived SARS-CoV-2 isolates when infecting Vero-E6 cells. (A) Time-series

284 plots of the $C_{t}$ values (corresponding to the multiplicative inverse of viral load) of the

285 SAR-CoV-2 ORF1a gene over the course of infectivity assay. Each viral isolate plus the

286 negative control "C" was color-coded accordingly. P-values were calculated using the

287 ANOVA method to compare the means of all 11 viral isolates at each time point,

288 excluding the negative control "C". (B) Time-series plots of the $\mathrm{C}_{t}$ values of the

289 SAR-CoV-2 ORF1a gene for each of the 11 patient-derived viral isolates. P-values were

290 calculated between consecutive time points using the t-test and adjusted p-values are

291 shown. 
medRxiv preprint doi: https://doi.org/10.1101/2020.04.14.20060160; this version posted April 23, 2020. The copyright holder for this preprint (which was not certified by peer review) is the author/funder, who has granted medRxiv a license to display the preprint in perpetuity.

All rights reserved. No reuse allowed without permission.

A
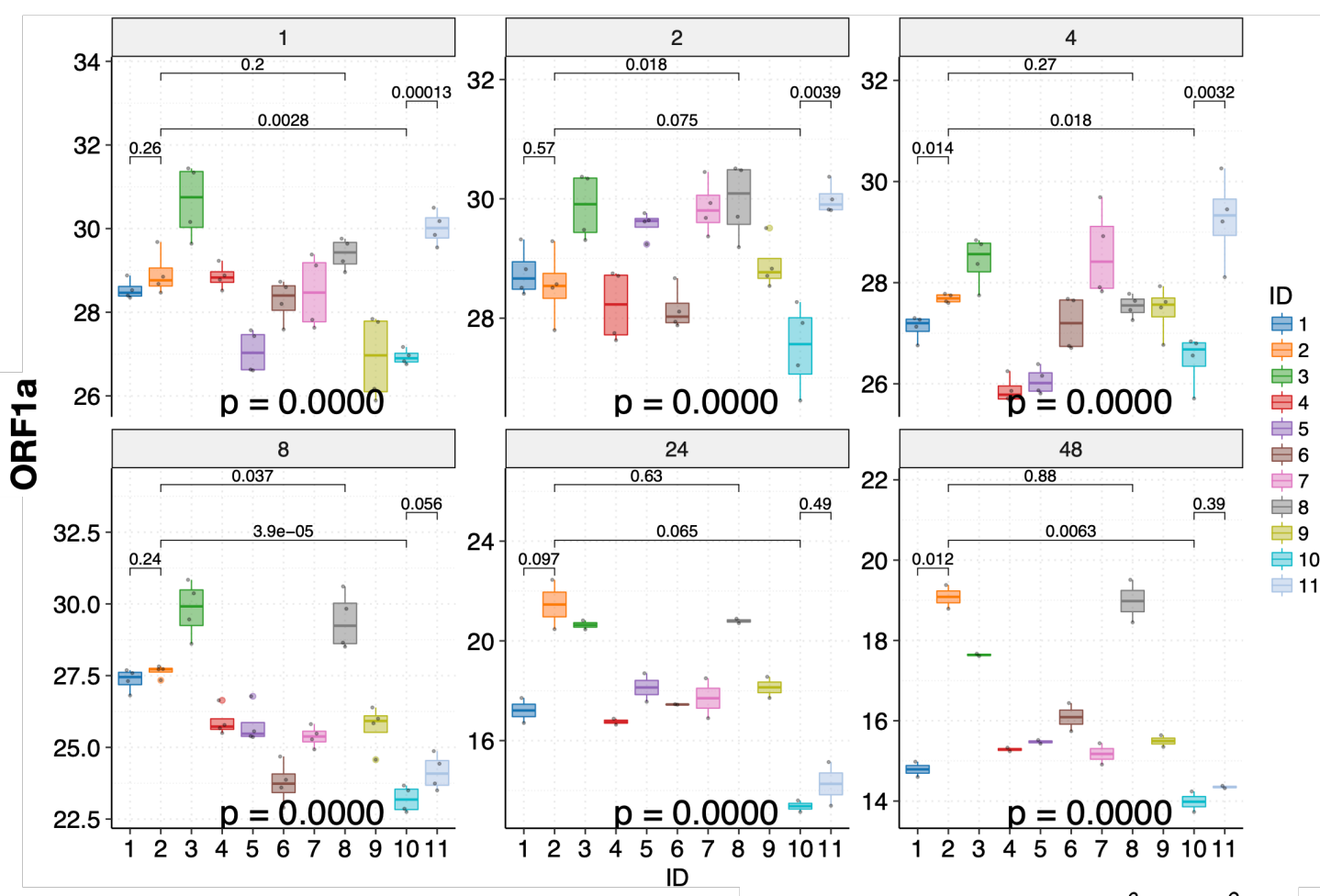

B

ZJU-11

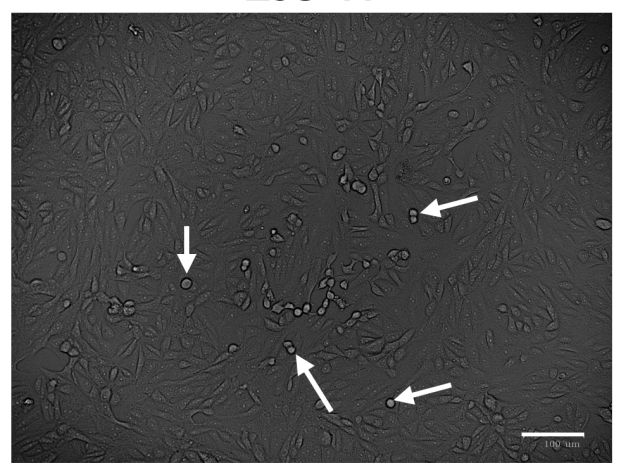

C
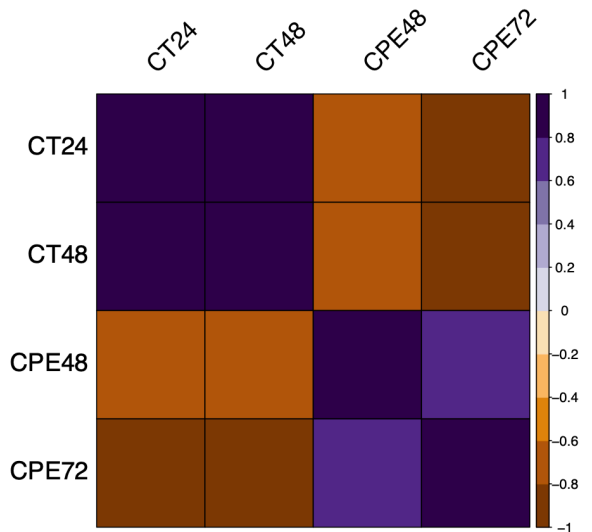

294 Fig. 4. The changes in CPE and viral load are highly correlated. (A) Significant

295 variations in viral load were observed at each time point. Mean $C_{t}$ values of selected viral

296 isolates are displayed and color-coded, respectively. P-values were calculated using the

297 ANOVA method to compare the means of all 11 viral isolates at each time point.

298 Pair-wise p-values were calculated between isolates using the t-test and adjusted p-values 
medRxiv preprint doi: https://doi.org/10.1101/2020.04.14.20060160; this version posted April 23, 2020. The copyright holder for this preprint

(which was not certified by peer review) is the author/funder, who has granted medRxiv a license to display the preprint in perpetuity.

All rights reserved. No reuse allowed without permission.

299 are shown. (B) Cytopathic effects were visible under the microscope 48 hours P.I., white

300 arrows indicate representative cells undergoing lysis. (C) Cytopathic effects (CPE) were

301 highly correlated with viral load (CT) in viral infectivity assay. Pearson correlations were

302 calculated and p-values were adjusted accordingly; only correlations with adjusted

303 p-value $<0.05$ are shown. Note that the CT values are negatively correlated with CPE

304 values because CT values represent the inverse number of viral loads.

Discussion

307 The quickly-developing COVID-19 pandemic has already infected millions of victims

308 and caused 70,000 deaths globally. While many ongoing research projects are attempting

309 to track the evolutionary origin of the virus, find the mechanisms of infection, and

310 produce vaccines or drugs against the virus, we sought to establish the

311 genotype-phenotype link behind the abundant diversity being observed as a result of

312 global sequencing efforts (GISAID). Due to the extremely wide variety of clinical

313 symptoms shown in the patients, establishing a genotype-phenotype link in patients

314 would be very difficult. The in vitro cell line provides an ideal system to examine the

315 mutational impact of different isolates of viruses, when all other confounding factors are 
medRxiv preprint doi: https://doi.org/10.1101/2020.04.14.20060160; this version posted April 23, 2020. The copyright holder for this preprint (which was not certified by peer review) is the author/funder, who has granted medRxiv a license to display the preprint in perpetuity.

All rights reserved. No reuse allowed without permission.

316 removed. Although the Vero-E6 cell line was not derived from human, the ACE2 protein

317 of the Vero-E6 cell line is highly similar to that of Human (Fig. S6) and we provided

318 direct evidence that the SARS-CoV-2 can infect the cell line (Fig. 2B).

319 Several findings stand out in our study: 1. A diverse collection of mutations was

320 identified in the 11 viral isolates, including two sets of founding mutations for two major

321 clusters of viruses currently infecting the world population. In addition, 19 of the 31

322 identified mutations are novel, despite the relatively early sampling dates, indicating that

323 the true diversity of the viral strains is still largely underappreciated; 2. remarkably, the

324 T22303G and A22301C mutations result in the same S247R mutation in the S protein

325 (Fig. 1 and S1), mapping to the existing structure revealed that this residue is located in a

326 flexible loop region within the N-terminal domain of the S1 subunit of S protein,

327 although the exact position of S247 could not be determined (Fig. S7, red arch). While

328 the N-terminal domain is not directly involved with binding to ACE2 (Walls et al., 2020)

329 we note that this domain is positioned right next to the $\mathrm{C}$-terminal domain, which binds to

330 ACE2. Interestingly, the T22303G mutation was observed in 5 viral isolates, albeit in

331 different proportions, indicating that this specific mutation was already present in the

332 early days of pandemic, and probably in a significant number of people of Wuhan, 
medRxiv preprint doi: https://doi.org/10.1101/2020.04.14.20060160; this version posted April 23, 2020. The copyright holder for this preprint (which was not certified by peer review) is the author/funder, who has granted medRxiv a license to display the preprint in perpetuity.

All rights reserved. No reuse allowed without permission.

333 despite the fact that it is still largely missing from current GISAID collection. This could

334 be due to the founding effect of mutations, in which case the T22303G mutation was not

335 transmitted out of the China during the early days; 3. The tri-nucleotide mutation in

336 ZJU-11 is unexpected; we note that this specific viral isolate is quite potent in our viral

337 load and CPE assay, and its patient remained positive for an astounding period of 45 days

338 and was only recently discharged from the hospital (Table 1). Investigating the functional

339 impact of this tri-nucleotide mutation would be highly interesting. We note that in the

340 current database, another trinucleotide mutation (G28881A, G2882A and G28883C) has

341 been identified, which also results in two missense mutations at the protein level (Fig. S8).

342 It leads to a cluster of more than 300 viral strains as of the time of writing this article, and

343 its mutational impact on the viral pathogenicity would be worth investigating. Finally, in

344 contrary to the recent report that a viable viral isolate could not be obtained from stool

345 samples, three of our viral isolated were extracted from stool samples, indicating that the

346 SARS-CoV-2 is capable of replicating in stool samples (Woelfel et al., 2020).

In short, our study provides direct evidence that mutations currently occurring in the

348 SARS-CoV-2 genome have the functional potential to impact the viral pathogenicity.

349 Therefore, viral surveillance should be also performed at the cellular level when possible, 
medRxiv preprint doi: https://doi.org/10.1101/2020.04.14.20060160; this version posted April 23, 2020. The copyright holder for this preprint

(which was not certified by peer review) is the author/funder, who has granted medRxiv a license to display the preprint in perpetuity.

All rights reserved. No reuse allowed without permission.

350 in addition to the accumulating genomic sequencing data. Furthermore, characterizations

351 of all founding mutations in the major geo-based clusters of viruses could be very useful

352 in helping determining if there are actionable pathogenicity differences to aid the current

353 battle against the virus. Finally, similar to flu, drug and vaccine development, while

354 urgent, need to take the impact of these accumulating mutations, especially the founding

355 mutations, into account to avoid potential pitfalls.

$357 \quad$ Figure legends

358 Table 1. A summary of the epidemiological information of the 11 patients involved in

359 this study. The "Viral gen" (viral generation) was inferred based on their exposure

360 history.

361 Fig. 1. A summary of the mutations identified in each of the 11 viral isolates. Each ORF

362 of the viral genome was denoted based on the annotations of NC_045512.2 as provided

363 by NCBI. If a mutation was observed in the context of a mixed population, the respective

364 percentages of the top two alleles are provided. Changes at the amino acid level are

365 provided if applicable. Blue color indicates novel mutation at the time of writing the 366 article. 
medRxiv preprint doi: https://doi.org/10.1101/2020.04.14.20060160; this version posted April 23, 2020. The copyright holder for this preprint (which was not certified by peer review) is the author/funder, who has granted medRxiv a license to display the preprint in perpetuity.

All rights reserved. No reuse allowed without permission.

367 Fig. 2. Characterizations of the patient-derived SARS-CoV-2 isolates. (A) Phylogenetic

368 analyses of the 11 viral isolates in the context of 725 SARS-CoV-2 sequences

369 downloaded from GISAID. The 1000-times bootstrapped maximum likelihood tree was

370 constructed to demonstrate the phylogenetic context of the 11 viral isolates. Major and

371 minor clusters were color-coded and denoted as shown in the "colored ranges" inset box.

372 All ZJU- samples were color-codded as green. The width of a branch indicates bootstrap

373 supporting level. (B) Fluorescent labeling of the viral S protein indicates that isolated

374 SAR-CoV-2 viral particles (Green) bind to the peripherals of the Vero-E6 cells (DNA

375 stained as Blue) prior to entry. Scale bars, $50 \mu \mathrm{m}$. (C) A representative TEM picture of

376 the isolated SAR-CoV-2 viral particles, arrows indicate the iconic "crown" consisted of S

377 proteins (Spike). Scale bar, $100 \mathrm{~nm}$.

378 Fig. 3. The infectivity assay reveals temporal variation in the viral load of the

379 patient-derived SARS-CoV-2 isolates when infecting Vero-E6 cells. (A) Time-series

380 plots of the $C_{t}$ values (corresponding to the multiplicative inverse of viral load) of the

381 SAR-CoV-2 ORF1a gene over the course of infectivity assay. Each viral isolate plus the

382 negative control "C" was color-coded accordingly. P-values were calculated using the 
medRxiv preprint doi: https://doi.org/10.1101/2020.04.14.20060160; this version posted April 23, 2020. The copyright holder for this preprint

(which was not certified by peer review) is the author/funder, who has granted medRxiv a license to display the preprint in perpetuity.

All rights reserved. No reuse allowed without permission.

383 ANOVA method to compare the means of all 11 viral isolates at each time point,

384 excluding the negative control "C". (B) Time-series plots of the $\mathrm{C}_{t}$ values of the

385 SAR-CoV-2 ORF1a gene for each of the 11 patient-derived viral isolates. P-values were

386 calculated between consecutive time points using the t-test and adjusted p-values are

387 shown.

388 Fig. 4. The changes in $\mathrm{CPE}$ and viral load are highly correlated. (A) Significant

389 variations in viral load were observed at each time point. Mean $\mathrm{C}_{\mathrm{t}}$ values of selected viral

390 isolates are displayed and color-coded, respectively. P-values were calculated using the

391 ANOVA method to compare the means of all 11 viral isolates at each time point.

392 Pair-wise p-values were calculated between isolates using the t-test and adjusted p-values

393 are shown. (B) Cytopathic effects were visible under the microscope 48 hours P.I., white

394 arrows indicate representative cells undergoing lysis. (C) Cytopathic effects (CPE) were

395 highly correlated with viral load (CT) in viral infectivity assay. Pearson correlations were

396 calculated and p-values were adjusted accordingly; only correlations with adjusted

397 p-value $<0.05$ are shown. Note that the CT values are negatively correlated with CPE

398 values because CT values represent the inverse number of viral loads. 
medRxiv preprint doi: https://doi.org/10.1101/2020.04.14.20060160; this version posted April 23, 2020. The copyright holder for this preprint

\section{Experimental Model and Subject Details}

403 Patients with confirmed COVID-19 were admitted in the First Affiliated Hospital from 404 Jan 19 to Mar 5, 2020. The First Affiliated Hospital, located in Hangzhou, Zhejiang 405 Province, China, is one of the major provincial hospitals designated to receive patients 406 with COVID-19 infection across the Zhejiang Province; therefore, patients with severe 407 symptoms outside of Hangzhou were also admitted. Starting Jan 10, 2020, all patients 408 presenting to the hospital's fever clinic were screened by clinical staff for COVID-19 409 infection utilizing criteria for suspected cases as defined by the National Health 410 Commission of China's clinical diagnosis and management guideline for COVID-19 411 (China National Health Committee, 2020). Briefly, patients were screened based on their

412 clinical symptoms and their risk of epidemiological exposure, including past travel to 413 Hubei Province or close contact with people who had visited Hubei Province during the 414 COVID-19 outbreak. As the pandemic continued to spread, the probability of 415 transmission outside of Hubei Province increased. The epidemiological exposure to 416 Hubei Province was not a prerequisite for suspected cases. All suspected cases were 417 determined by laboratory tests and based on positive results of qRT-PCR assay for 418 COVID-19. Patients were excluded if two qRT-PCR tests 24 hours apart both suggested 
medRxiv preprint doi: https://doi.org/10.1101/2020.04.14.20060160; this version posted April 23, 2020. The copyright holder for this preprint (which was not certified by peer review) is the author/funder, who has granted medRxiv a license to display the preprint in perpetuity.

All rights reserved. No reuse allowed without permission.

419 negative results. Patients' clinical samples which PCR test $C_{t}$ value less than 28 were 420 collected to isolate SARS-Cov-2.

422 Method Details

423 Sample collection, Viral isolation, cell infection, and electron microscopy

424 All samples, sources including sputum, nasopharyngeal swab, and stool, were collected 425 from patients with COVID-19 with consent from all patients. The study was approved by 426 the Clinical Research Ethics Committee of The First Affiliated Hospital, School of 427 Medicine, Zhejiang University (Approval notice 2020-29) for emerging infectious 428 diseases. All collected samples were sent to BSL-3 lab for viral isolation within 4 hours.

429 The sputum, stool, and nasopharyngeal swab samples were pre-processed by first 430 mixing with appropriate volume (Sputum, 5-10 volumes; Stool, $2 \mathrm{ml} / 100 \mathrm{mg}$; 431 Nasopharyngeal swab, 1 volume) of MEM medium with 2\% FBS, Amphotericin B (100 $432 \mathrm{ng} / \mathrm{ml})$, Penicillin G (200 units/ml), Streptomycin $(200 \mu \mathrm{g} / \mathrm{ml})$, and TPCK-trypsin (4 $433 \mu \mathrm{g} / \mathrm{ml}$ ). The supernatant was collected after centrifugation at $3000 \mathrm{rpm}$ at room 434 temperature. Before infecting Vero-E6 cells, all collected supernatant was filtered using a $435 \quad 0.45 \mu \mathrm{m}$ filter to remove cell debris etc.

436 For viral infection and isolation, $3 \mathrm{ml}$ of filtered supernatant was added to Vero-E6 437 cells in a T25 culture flask. After incubation at $35^{\circ} \mathrm{C}$ for $2 \mathrm{~h}$ to allow binding, the 438 inoculum was removed and replaced with fresh culture medium. The cells were incubated 439 at $35^{\circ} \mathrm{C}$ and observed daily to evaluate cytopathic effects (CPE). The supernatant was 
medRxiv preprint doi: https://doi.org/10.1101/2020.04.14.20060160; this version posted April 23, 2020. The copyright holder for this preprint (which was not certified by peer review) is the author/funder, who has granted medRxiv a license to display the preprint in perpetuity.

All rights reserved. No reuse allowed without permission.

440 tested for SARS-CoV-2 by qRT-PCR (see below for qRT-PCR protocol). Once the

441 qRT-PCR test shows positive (typically after 4-5 days of incubation), the viral particles

442 were collected from culture supernatant by ultra-speed centrifugation $(100,000 \mathrm{x}$ g for 2

443 hours) for downstream sequencing, infectivity assay, and were observed under $200 \mathrm{kV}$

444 Tecnai G2 electron microscope.

\section{Immunofluorescence staining}

447 Vero-E6 Cells were infected by SARS-CoV-2 for 24 hours, and then fixed in $80 \%$ 448 acetone (chilled at $-20^{\circ} \mathrm{C}$ ) at room temperature for $10 \mathrm{~min}$. The cells were washed three 449 times with ice-cold PBS, blocked with 1\% BSA for $30 \mathrm{~min}$, and incubated with 450 SARS-CoV-2 Spike rabbit monoclonal antibody (dilution ratio 1:200) at room 451 temperature for 1 hour. The cells were again washed three times in ice-cold PBS, and 452 then stained with the Alexa Fluor488®-conjugated Goat Anti-rabbit IgG secondary 453 antibody (Abcam, Cat No. ab150077) for 1 hour at room temperature in the dark. The 454 cells were washed three times and then incubated in $0.5 \mu \mathrm{g} / \mathrm{mL}$ DAPI (nuclear DNA stain) 455 for $5 \mathrm{~min}$. Immunofluorescence was detected and picture were taken using the IX81 456 Olympus microscope equipped with a fluorescence apparatus.

\section{Viral infectivity assay}

Vero-E6 cells were grown in a 24-well plate and infected with different SARS-CoV-2

460 isolates in duplicates at MOI of 0.5. The inoculum was removed at 1 hours P.I. for the

461 1-hour timepoint group and at 2 hours P.I. for other timepoint groups. After incubation, 
medRxiv preprint doi: https://doi.org/10.1101/2020.04.14.20060160; this version posted April 23, 2020. The copyright holder for this preprint

(which was not certified by peer review) is the author/funder, who has granted medRxiv a license to display the preprint in perpetuity.

All rights reserved. No reuse allowed without permission.

462 the cultures were rinsed with PBS for three times and replenished with $1 \mathrm{~mL}$ fresh culture

463 medium. Then, the cultures were subjected to freezing immediately at $-80^{\circ} \mathrm{C}$ for the 1 -

464 and 2-hours samples, or continued to grow for the other groups $(4,8,24$ and 48 hours)

465 until harvest. Finally, all frozen samples from each timepoint were thawed together and

466 the viral nucleic acid abundance was measured with SARS-CoV-2 qRT-PCR Kits,

467 targeting ORF1a, E, and N genes (Liferiver Biotech, Shanghai). Results from the first

468 two time points reflect the capacity of viral attachment or entry into the target cells, while

469 results from the latter four time points represent the viral replication dynamics.

471 Cytopathic effect (CPE) evaluation

472 Vero-E6 cell monolayers were grown and infected by different patient-derived

473 SARS-CoV-2 isolates as described in the viral infectivity assay. At 24, 48, and 72 hours

474 P.I., virus induced cytopathic effects were observed with a digital microscope (Bio-Rad)

475 and pictures were taken. No obvious CPE was observed at 24 hours P.I.. Pictures taken at

47648 and 72 hours P.I. were evaluated first by expert opinions and then quantitated by cell

477 death ratio.

478 
medRxiv preprint doi: https://doi.org/10.1101/2020.04.14.20060160; this version posted April 23, 2020. The copyright holder for this preprint

(which was not certified by peer review) is the author/funder, who has granted medRxiv a license to display the preprint in perpetuity.

All rights reserved. No reuse allowed without permission.

479 Sequencing library construction

480 The total RNA in each deactivated viral sample was extracted using a viral RNA mini kit

481 (Qiagen, Germany). The sequencing library was constructed using the Total RNA-Seq

482 Kit (Kapa, Switzerland) and deep-sequenced on the illumina Novaseq 6000 platform (2 x

483151 bases; Illumina Inc., San Diego, CA) by BGI genomics.

484

485 Quantification and Statistical Analysis

486 Statistical Analyses and visualization

487 The majority of statistical analyses and visualizations were done in Rstudio and R (at the

488 time of writing, 1.0143 for Rstudio and 3.4.0 for R), with necessary aid from customized

489 python scripts (2.7.4) and shell scripts (Linux). The primary R packages are mostly

490 maintained by the Bioconductor project (https://www.bioconductor.org/, along with all

491 their dependencies). The essential ones used are ggplot2 (2.2.1), reshape2 (1.4.3),

492 RColorBrewer (1.1-2), scales (0.5.0), corrplot (0.84), Hmisc (4.1-1), ggrepel (0.7.0),

493 cluster (2.0.6), factoextra (1.0.5), plyr (1.8.4), dplyr (0.7.4), psych (1.7.8), devtools

494 (1.13.4), ggpubr (0.1.6), tidyverse (1.2.1), gridExtra (2.3), ggsci (2.8), ggbeeswarm

495 (0.6.0), ggpmisc (0.2.16), colorspace (1.3-2). 
medRxiv preprint doi: https://doi.org/10.1101/2020.04.14.20060160; this version posted April 23, 2020. The copyright holder for this preprint

(which was not certified by peer review) is the author/funder, who has granted medRxiv a license to display the preprint in perpetuity.

All rights reserved. No reuse allowed without permission.

In general, parametric statistical tests (t-test, Anova, and Pearson correlation) were

497 used when the data distribution conforms to normality distribution (such as qPCR

498 measurements), and non-parametric statistical tests (Wilcoxon test, Kruskal-Wallis, and

499 Spearman correlation) were used when datasets do not conform to the normality

500 assumption. We adjust the $\mathrm{p}$ values using the Benjamini \& Hochberg $(\mathrm{BH})$ method

501 (Benjamini and Yekutieli, 2001) to control for False Discovery Rate (FDR), when

502 multiple comparisons are concerned, including $\mathrm{p}$ value matrix constructed when

503 calculating correlations matrix among different features or samples.

504 The 3D structure of the $\mathrm{S}$ protein was visualized and downloaded from

505 https://www.rcsb.org/3d-view/6VSB/1.

507 Sequence data processing, de novo assembling, and mutation identifications

508 Sequencing data was generated from Novaseq 6000 and first filtered of low quality and

509 high barcode contamination by Soapnuke and then mapped to 43 complete genome

510 references of 2019-nCoV (SARS-CoV-2) by BWA-MEM (Li and Durbin, 2009).

511 References of SARS-CoV-2 were downloading from NCBI on date February 28th, 2020.

512 Further, mapping reads that longer than 100nt were extracted for de novo assemby by 
medRxiv preprint doi: https://doi.org/10.1101/2020.04.14.20060160; this version posted April 23, 2020. The copyright holder for this preprint (which was not certified by peer review) is the author/funder, who has granted medRxiv a license to display the preprint in perpetuity.

All rights reserved. No reuse allowed without permission.

513 SPAdes (Bankevich et al., 2012) (v3.1.3) using an iterative short-read genome assembly

514 module for pair-end reads. K-values were selected automatically at 33nt, 55nt and 77nt

515 for these samples. After assembling, contigs was blasted to nt database (20190301) to

516 confirm their origins, and only contigs belonging to coronavirus were retained for base

517 correction. Next, filtering reads of each sample were mapped back to retained assembled

518 contigs and bam-readcount was applied (--min-mapping-quality=5, other parameter was

519 set default) to calculate the base frequency of every post of each assemble contigs.

520 Meanwhile, Haplotypecaller of gatk was applied to call snp/indel based on the assembled

521 contigs with reads quality higher than 20. Finally, bam files were inspected in igv

522 manually to verify each mutation based on the number of reads mapped, the balance

523 between reads mapped to plus and minus strands of the reference genome, and the

524 relative positions of the mutations on these reads.

\section{Phylogenetic analysis}

527 We acquired 725 high quality and high coverage SARS-CoV-2 genomes from GISAID

528 (downloaded on 3/21/2020), including the Yunnan RaTG13 viral strain and the

529 Guangdong pangolin viral strain as the outgroup. We aligned the 736 genomic sequences 
medRxiv preprint doi: https://doi.org/10.1101/2020.04.14.20060160; this version posted April 23, 2020. The copyright holder for this preprint (which was not certified by peer review) is the author/funder, who has granted medRxiv a license to display the preprint in perpetuity.

All rights reserved. No reuse allowed without permission.

530 with MAFFT (Katoh and Standley, 2013) with options --thread 16 --globalpair

531 --maxiterate 1000 and trimmed the full-length alignment with trimAL (Capella-Gutiérrez

532 et al., 2009) using the -automated1 option to remove any spurious parts of the alignment,

533 which could introduce noise to the phylogenetic analysis process. We used iqtree

534 (Nguyen et al., 2015) with options -bb 1000 -alrt 1000 -nt 64 -asr to construct a

535 1000-times bootstrapped maximum-likelihood phylogenic tree of the 736 viral sequences

536 based on 835 parsimony informative sites. The resulting phylogenetic tree was imported

537 in iTOL and visualized (Letunic and Bork, 2011). We conducted Tajima's test of

538 neutrality based on the constructed alignment of viral sequences using MEGA 7 (Kumar

539 et al., 2016).

541 Data and Software Availability

542 The full-genome sequences of the 11 viral isolates have been deposited to the GISAID

543 collection with the following IDs: EPI_ISL_415709, EPI_ISL_416042, EPI_ISL_416044,

544 EPI_ISL_416046, EPI_ISL_415711, EPI_ISL_416047, EPI_ISL_416425,

545 EPI_ISL_416473, EPI_ISL_416474, EPI_ISL_418990, and EPI_ISL_418991. 


\section{Supplementary Figure Legends}

547 Table S1. A summary of the sequencing statistics of the 11 viral isolates involved in the

548 study, Related to Figure 1. Note that ZJU_10 and ZJU_11 were sequenced in a different

549 batch.

550 Fig. S1. A summary of the nucleotide mutations that lead to the S247R mutations

551 observed in the 11 patient-derived isolates, Related to Figure 1. Note that some of the

552 mutations are in the form of minor alleles. Images were produced by IGV.

553 Fig. S2. A summary of additional mutations in the $\mathrm{S}$ gene and the tri-nucleotide mutation,

554 Related to Figure 1. Note that some of the mutations are in the form of minor alleles.

555 Images were produced by IGV.

556 Fig. S3. Phylogenetic analyses produced from GISAID using time (top) or number of

557 mutations (bottom) as the branch length, Related to Figure 2. Note that all three major

558 clusters described in the study are labeled accordingly. The major distinction is that the

559 ORF8-L84S clade is not monophyletic in our more computationally intensive and

560 bootstrapping-supported approach. 
medRxiv preprint doi: https://doi.org/10.1101/2020.04.14.20060160; this version posted April 23, 2020. The copyright holder for this preprint (which was not certified by peer review) is the author/funder, who has granted medRxiv a license to display the preprint in perpetuity.

All rights reserved. No reuse allowed without permission.

561 Fig. S4. The characterizations of the 11 viral isolates, Related to Figure 2 and Figure 4.

562 (A) A representative TEM picture of the isolated SAR-CoV-2 viral particles, arrows

563 indicate the iconic "crown" consisted of S proteins (Spike). (B) Time-series plots of the

$564 \mathrm{C}_{\mathrm{t}}$ values (corresponding to the multiplicative inverse of viral load) of the SAR-CoV-2 E

565 gene (top) and $\mathrm{N}$ gene (bottom) over the course of infectivity assay. Each viral isolate

566 plus the negative control "C" was color-coded accordingly. P-values were calculated

567 using the ANOVA method to compare the means of all 11 viral isolates at each time

568 point, excluding the negative control "C". (C) Time-series plots of the $\mathrm{C}_{t}$ values of the

569 SAR-CoV-2 E gene (left) and $\mathrm{N}$ gene (right) for each of the 11 patient-derived viral

570 isolates. P-values were calculated between consecutive time points using the t-test and

571 adjusted p-values are shown.

572 Fig. S5. Significant variations were observed in viral load and viral CPE among the 11

573 patient-derived isolates, Related to Figure 4. (A) Significant variations in viral load can

574 be observed based on $\mathrm{E}$ gene (left) and $\mathrm{N}$ gene (right). (B) CPE at $48 \mathrm{~h}$ and $72 \mathrm{~h}$ P.I. as

575 evaluated by an expert's opinions. (C) CPE at $48 \mathrm{~h}$ and $72 \mathrm{~h}$ P.I. evaluated by quantitively

576 calculating the cell death ratio (ratio.dead) for 1-3 images per viral isolate. The results 
medRxiv preprint doi: https://doi.org/10.1101/2020.04.14.20060160; this version posted April 23, 2020. The copyright holder for this preprint

(which was not certified by peer review) is the author/funder, who has granted medRxiv a license to display the preprint in perpetuity.

All rights reserved. No reuse allowed without permission.

577 from (B) and (C) are highly correlated (R $>0.89, \mathrm{p}<0.001)$. (D) Representative images

578 used for CPE evaluation, arrows indicate cells facing immediate death. Scale bars, 100

$579 \mu \mathrm{m}$.

580 Fig. S6. The alignment of ACE2 protein sequences from human (Homo), Chimpanzee,

581 and green monkey (from which the Vero-E6 cell line was derived), Related to Figure 2.

582 Note that overall the ACE2 proteins are highly similar to each other. The alignment and

583 image were produced by Jalview.

584 Fig. S7. The 3D structure of the S-protein with the S247R overlay, Related to Figure 1.

585 The top (A), bottom (B), side (C), and close-up view (D) were provided. Note that the

586 actual position of S247 was not determined in the original structure, hence a small red arc

587 was in place to represent to the potential flexible loop conformation for (C) and (D). Also

588 note that the protein complex is trimeric, but only one of the three mutations was labeled.

589 The 3D structure of the $\mathrm{S}$ protein was visualized and downloaded from 
medRxiv preprint doi: https://doi.org/10.1101/2020.04.14.20060160; this version posted April 23, 2020. The copyright holder for this preprint

(which was not certified by peer review) is the author/funder, who has granted medRxiv a license to display the preprint in perpetuity.

All rights reserved. No reuse allowed without permission.

591 Fig. S8. The trinucleotide mutation (G28881A, G28882A, and G28883C) was identified

592 in the GISAID dataset and is the founding mutation for a large cluster of viral isolates

593 within the S-D614G group (European clade), Related to Figure 1.

594 Author Contributions

595 M.Z., C.J., N.W., and L.L conceived and supervised the study. H.Y. and X.L. performed

596 all the experiments, with help from K.X., Y.C., L.C., F.L., Z.W., H.W., and C. Jin. C.J.,

597 M.Z., and Q.C. performed all the data analyses. C.J., Q.C., H.Y., and M.Z. drafted and

598 revised the manuscript with input from all authors.

599 Acknowledgments

600 We gratefully acknowledge Drs. X. Zhu, L. Xiang, J. Jensen, and M. Lynch for their

601 helpful discussions. We thank Dr. V. Billing for her help on improving the manuscript.

$602 \quad$ Funding

603 This work was supported by funds from Major Project of Zhejiang Provincial Science

604 and Technology Department \#2020C03123, National Science and Technology Major

605 Project for the Control and Prevention of Major Infectious Diseases in China 
607 Sciences Institute at Zhejiang University.

608

609 None

\section{References}

611 Bai, Y., Yao, L., Wei, T., Tian, F., Jin, D.Y., Chen, L., and Wang, M. (2020). Presumed Asymptomatic

612 Carrier Transmission of COVID-19. JAMA - J. Am. Med. Assoc.

613 Bankevich, A., Nurk, S., Antipov, D., Gurevich, A.A., Dvorkin, M., Kulikov, A.S., Lesin, V.M., Nikolenko,

614 S.I., Pham, S., Prjibelski, A.D., et al. (2012). SPAdes: A new genome assembly algorithm and its

615 applications to single-cell sequencing. J. Comput. Biol. 19, 455-477.

616 Bauch, C.T., Lloyd-Smith, J.O., Coffee, M.P., and Galvani, A.P. (2005). Dynamically modeling SARS and

617 other newly emerging respiratory illnesses: Past, present, and future. Epidemiology 16, 791-801.

618 Benjamini, Y., and Yekutieli, D. (2001). The control of the false discovery rate in multiple testing under

619 dependency. Ann. Stat. 29, 1165-1188.

620 Cao, B., Wang, Y., Wen, D., Liu, W., Wang, J., Fan, G., Ruan, L., Song, B., Cai, Y., Wei, M., et al. (2020). A

621 Trial of Lopinavir-Ritonavir in Adults Hospitalized with Severe Covid-19. N. Engl. J. Med. 1-13. 
medRxiv preprint doi: https://doi.org/10.1101/2020.04.14.20060160; this version posted April 23, 2020. The copyright holder for this preprint

(which was not certified by peer review) is the author/funder, who has granted medRxiv a license to display the preprint in perpetuity.

All rights reserved. No reuse allowed without permission.

622 Capella-Gutiérrez, S., Silla-Martínez, J.M., and Gabaldón, T. (2009). trimAl: A tool for automated

623 alignment trimming in large-scale phylogenetic analyses. Bioinformatics.

624 Capobianchi, M.R., Rueca, M., Messina, F., Giombini, E., Carletti, F., Colavita, F., Castilletti, C., Lalle, E.,

625 Bordi, L., Vairo, F., et al. (2020). Molecular characterization of SARS-CoV-2 from the first case of

626 COVID-19 in Italy. Clin Microbiol Infect 0.

627 China National Health Committee (2020). COVID-19 clinical diagnosis and management guideline issued

628 by National Health Commission of China, the 5th edition.

629 Corman, V.M., Muth, D., Niemeyer, D., and Drosten, C. (2018). Hosts and Sources of Endemic Human

630 Coronaviruses. In Advances in Virus Research, pp. 163-188.

631 van Doremalen, N., Bushmaker, T., Morris, D.H., Holbrook, M.G., Gamble, A., Williamson, B.N., Tamin,

632 A., Harcourt, J.L., Thornburg, N.J., Gerber, S.I., et al. (2020). Aerosol and Surface Stability of

633 SARS-CoV-2 as Compared with SARS-CoV-1. N. Engl. J. Med.

634 Forni, D., Cagliani, R., Clerici, M., and Sironi, M. (2017). Molecular Evolution of Human Coronavirus

635 Genomes. Trends Microbiol. 25, 35-48.

636 Guan, W., Ni, Z., Hu, Y., Liang, W., Ou, C., He, J., Liu, L., Shan, H., Lei, C., Hui, D.S., et al. (2020).

637 Clinical characteristics of 2019 novel coronavirus infection in China. N. Engl. J. Med.

638 Hoffmann, M., Kleine-Weber, H., Schroeder, S., Krüger, N., Herrler, T., Erichsen, S., Schiergens, T.S., 
medRxiv preprint doi: https://doi.org/10.1101/2020.04.14.20060160; this version posted April 23, 2020. The copyright holder for this preprint

(which was not certified by peer review) is the author/funder, who has granted medRxiv a license to display the preprint in perpetuity.

All rights reserved. No reuse allowed without permission.

639 Herrler, G., Wu, N.-H., Nitsche, A., et al. (2020). SARS-CoV-2 Cell Entry Depends on ACE2 and

640 TMPRSS2 and Is Blocked by a Clinically Proven Protease Inhibitor. Cell 1-10.

641 Hu, Z., Song, C., Xu, C., Jin, G., Chen, Y., Xu, X., Ma, H., Chen, W., Lin, Y., Zheng, Y., et al. (2020).

642 Clinical characteristics of 24 asymptomatic infections with COVID-19 screened among close contacts in

643 Nanjing, China. Sci. China Life Sci.

644 Katoh, K., and Standley, D.M. (2013). MAFFT Multiple Sequence Alignment Software Version 7:

645 Improvements in Performance and Usability. Mol. Biol. Evol. 30, 772-780.

646 Kumar, S., Stecher, G., and Tamura, K. (2016). MEGA7: Molecular Evolutionary Genetics Analysis

647 Version 7.0 for Bigger Datasets. Mol. Biol. Evol.

648 Lauer, S.A., Grantz, K.H., Bi, Q., Jones, F.K., Zheng, Q., Meredith, H.R., Azman, A.S., Reich, N.G., and

649 Lessler, J. (2020). The Incubation Period of Coronavirus Disease 2019 (COVID-19) From Publicly

650 Reported Confirmed Cases: Estimation and Application. Ann. Intern. Med.

651 Letunic, I., and Bork, P. (2011). Interactive Tree of Life v2: Online annotation and display of phylogenetic

652 trees made easy. Nucleic Acids Res. 39, W475-W478.

653 Li, H., and Durbin, R. (2009). Fast and accurate short read alignment with Burrows-Wheeler transform.

654 Bioinformatics 25, 1754-1760.

655 Lin, Q., Chiu, A.P.Y., Zhao, S., and He, D. (2018). Modeling the spread of Middle East respiratory 
medRxiv preprint doi: https://doi.org/10.1101/2020.04.14.20060160; this version posted April 23, 2020. The copyright holder for this preprint

(which was not certified by peer review) is the author/funder, who has granted medRxiv a license to display the preprint in perpetuity.

All rights reserved. No reuse allowed without permission.

656 syndrome coronavirus in Saudi Arabia. Stat. Methods Med. Res. 27, 1968-1978.

657 Lipsitch, M., Cohen, T., Cooper, B., Robins, J.M., Ma, S., James, L., Gopalakrishna, G., Chew, S.K., Tan,

658 C.C., Samore, M.H., et al. (2003). Transmission dynamics and control of severe acute respiratory syndrome.

659 Science (80-. ). 300, 1966-1970.

660 Liu, Y., Gayle, A.A., Wilder-Smith, A., and Rocklöv, J. (2020). The reproductive number of COVID-19 is

661 higher compared to SARS coronavirus. J. Travel Med.

662 Lu, R., Zhao, X., Li, J., Niu, P., Yang, B., Wu, H., Wang, W., Song, H., Huang, B., Zhu, N., et al. (2020).

663 Genomic characterisation and epidemiology of 2019 novel coronavirus: implications for virus origins and

664 receptor binding. Lancet 395, 565-574.

665 Lv, L., Li, G., Chen, J., Liang, X., and Li, Y. (2020). Comparative genomic analysis revealed specific

666 mutation pattern between human coronavirus SARS-CoV-2 and Bat-SARSr-CoV RaTG13. BioRxiv

$667 \quad 2020.02 .27 .969006$.

668 Lynch, M. (2007). The Origins of Genome Architecture.

669 Nguyen, L.T., Schmidt, H.A., Von Haeseler, A., and Minh, B.Q. (2015). IQ-TREE: A fast and effective

670 stochastic algorithm for estimating maximum-likelihood phylogenies. Mol. Biol. Evol.

671 Ou, J., Zhou, Z., Zhang, J., Lan, W., Zhao, S., Wu, J., Seto, D., Zhang, G., and Zhang, Q. (2020). RBD

672 mutations from circulating SARS-CoV-2 strains enhance the structure stability and infectivity of the spike 
medRxiv preprint doi: https://doi.org/10.1101/2020.04.14.20060160; this version posted April 23, 2020. The copyright holder for this preprint

(which was not certified by peer review) is the author/funder, who has granted medRxiv a license to display the preprint in perpetuity.

All rights reserved. No reuse allowed without permission.

673

protein. BioRxiv 2020.03.15.991844.

674 Renzette, N., Pfeifer, S.P., Matuszewski, S., Kowalik, T.F., and Jensen, J.D. (2017). On the Analysis of

675 Intrahost and Interhost Viral Populations: Human Cytomegalovirus as a Case Study of Pitfalls and

676 Expectations. J. Virol. 91, e01976-16.

677 Schneider, M., Ackermann, K., Stuart, M., Wex, C., Protzer, U., Schätzl, H.M., and Gilch, S. (2012). Severe

678 Acute Respiratory Syndrome Coronavirus Replication Is Severely Impaired by MG132 due to

679 Proteasome-Independent Inhibition of M-Calpain. J. Virol. 86, 10112-10122.

680 Tajima, F. (1989). Statistical method for testing the neutral mutation hypothesis by DNA polymorphism.

681 Tortorici, M.A., and Veesler, D. (2019). Structural insights into coronavirus entry. In Advances in Virus

682 Research, pp. 93-116.

683 Varia, M., Wilson, S., Sarwal, S., McGeer, A., Gournis, E., Galanis, E., and Henry, B. (2003). Investigation

684 of a nosocomial outbreak of severe acute respiratory syndrome (SARS) in Toronto, Canada. Cmaj 169,

$685 \quad 285-292$.

686 Virlogeux, V., Fang, V.J., Park, M., Wu, J.T., and Cowling, B.J. (2016). Comparison of incubation period

687 distribution of human infections with MERS-CoV in South Korea and Saudi Arabia. Sci. Rep. 6.

688 Walls, A.C., Park, Y.-J., Tortorici, M.A., Wall, A., McGuire, A.T., and Veesler, D. (2020). Structure,

689 Function, and Antigenicity of the SARS-CoV-2 Spike Glycoprotein. Cell. 
medRxiv preprint doi: https://doi.org/10.1101/2020.04.14.20060160; this version posted April 23, 2020. The copyright holder for this preprint

(which was not certified by peer review) is the author/funder, who has granted medRxiv a license to display the preprint in perpetuity.

All rights reserved. No reuse allowed without permission.

690 Wang, Z., and Xu, X. (2020). scRNA-seq profiling of human testes reveals the presence of ACE2 receptor,

691 a target for SARS-CoV-2 infection, in spermatogonia, Leydig and Sertoli cells. Viruses 1-16.

692 Wang, C., Li, W., Drabek, D., Okba, N.M.A., Haperen, R. van, Osterhaus, A.D.M.E., Kuppeveld, F.J.M.

693 van, Haagmans, B.L., Grosveld, F., and Bosch, B.-J. (2020). A human monoclonal 1 antibody blocking

694 SARS-CoV-2 infection. BioRxiv 2020.03.11.987958.

695 Woelfel, R., Corman, V.M., Guggemos, W., Seilmaier, M., Zange, S., Mueller, M.A., Niemeyer, D., Vollmar,

696 P., Rothe, C., Hoelscher, M., et al. (2020). Clinical presentation and virological assessment of hospitalized

697 cases of coronavirus disease 2019 in a travel-associated transmission cluster. MedRxiv

$698 \quad 2020.03 .05 .20030502$.

699 Wu, F., Zhao, S., Yu, B., Chen, Y.M., Wang, W., Song, Z.G., Hu, Y., Tao, Z.W., Tian, J.H., Pei, Y.Y., et al.

700 (2020). A new coronavirus associated with human respiratory disease in China. Nature 579, $265-269$.

701 Xiao, F., Tang, M., Zheng, X., Liu, Y., Li, X., and Shan, H. (2020). Evidence for gastrointestinal infection

702 of SARS-CoV-2. Gastroenterology.

703 Yu, W.-B. (2020). Decoding evolution and transmissions of novel pneumonia coronavirus (SARS-CoV-2)

704 using the whole genomic data Comparative analyses of the chloroplast genome in carnivorous plants View

705 project. ChinaXriv.

706 Zhao, Y., Zhao, Z., Wang, Y., Zhou, Y., Ma, Y., and Zuo, W. (2020). Single-cell RNA expression profiling 
medRxiv preprint doi: https://doi.org/10.1101/2020.04.14.20060160; this version posted April 23, 2020. The copyright holder for this preprint (which was not certified by peer review) is the author/funder, who has granted medRxiv a license to display the preprint in perpetuity. All rights reserved. No reuse allowed without permission.

707 of ACE2, the putative receptor of Wuhan 2019-nCov. BioRxiv 2020.01.26.919985.

708 Zhou, P., Yang, X. Lou, Wang, X.G., Hu, B., Zhang, L., Zhang, W., Si, H.R., Zhu, Y., Li, B., Huang, C.L.,

709 et al. (2020). A pneumonia outbreak associated with a new coronavirus of probable bat origin. Nature 579,

$710 \quad 270-273$.

711 Zhu, N., Zhang, D., Wang, W., Li, X., Yang, B., Song, J., Zhao, X., Huang, B., Shi, W., Lu, R., et al. (2020).

712 A novel coronavirus from patients with pneumonia in China, 2019. N. Engl. J. Med. 382, 727-733.

713 


\begin{tabular}{|c|c|c|c|c|c|c|c|c|}
\hline ID & Raw reads & Clean reads & $\begin{array}{c}\text { Raw } \\
\text { bases }(G)\end{array}$ & $\begin{array}{c}\text { Clean } \\
\text { bases(G) }\end{array}$ & coverage & Clean rate & $\underset{1}{\text { Error_rate_fq }}$ & $\begin{array}{c}\text { Error_rate_fq } \\
2\end{array}$ \\
\hline \multicolumn{8}{|c|}{ 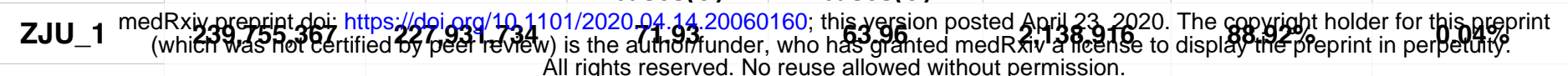 } & $0.04 \%$ \\
\hline ZJU_2 & $211,974,282$ & $195,211,677^{A}$ & $\begin{array}{c}\text { hts reserved. } \\
63.59\end{array}$ & $\begin{array}{l}\text { use allowed } n \\
53.28\end{array}$ & $\begin{array}{l}\text { permission. } \\
\mathbf{1 , 7 8 1 , 7 6 1}\end{array}$ & $83.78 \%$ & $0.04 \%$ & $0.04 \%$ \\
\hline ZJU_3 & $421,726,717$ & $378,718,257$ & 126.52 & 103.91 & $3,474,902$ & $82.13 \%$ & $0.04 \%$ & $0.04 \%$ \\
\hline ZJU_4 & $485,306,221$ & $434,439,201$ & 145.59 & 118.99 & $3,979,199$ & $81.73 \%$ & $0.04 \%$ & $0.04 \%$ \\
\hline ZJU_5 & $232,311,525$ & $205,222,721$ & 69.69 & 56.11 & $1,876,400$ & $80.52 \%$ & $0.04 \%$ & $0.04 \%$ \\
\hline ZJU_6 & $342,183,998$ & $273,708,578$ & 102.66 & 70.92 & $2,371,668$ & $69.09 \%$ & $0.04 \%$ & $0.04 \%$ \\
\hline ZJU_7 & $227,769,540$ & $191,916,976$ & 68.33 & 52.18 & $1,744,975$ & $76.37 \%$ & $0.04 \%$ & $0.05 \%$ \\
\hline ZJU_8 & $355,648,629$ & $331,651,060$ & 106.69 & 90.7 & $3,033,140$ & $85.01 \%$ & $0.04 \%$ & $0.04 \%$ \\
\hline ZJU_9 & $287,524,792$ & $260,634,803$ & 86.26 & 72.7 & $2,431,194$ & $84.28 \%$ & $0.04 \%$ & $0.04 \%$ \\
\hline ZJU_10 & $136,595,606$ & $101,832,137$ & 40.98 & 28.24 & 944,387 & $68.91 \%$ & $0.02 \%$ & $0.03 \%$ \\
\hline ZJU_11 & $121,791,338$ & $96,729,474$ & 36.54 & 27.76 & 928,335 & $75.98 \%$ & $0.02 \%$ & $0.03 \%$ \\
\hline Average & $278,417,092$ & $245,272,420$ & 83.53 & 67.16 & $2,245,898$ & $79.70 \%$ & $0.04 \%$ & $0.04 \%$ \\
\hline
\end{tabular}

Table S1. A summary of the sequencing statistics of the 11 viral isolates involved in the study. Note that ZJU_10 and ZJU_11 were sequenced in a different batch. 


\section{T22303G \\ $\mathrm{T}: \mathrm{G}=\mathbf{8 0} \%: 20 \%$}

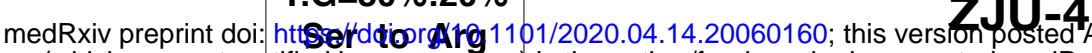
priv a license to display the preprint in perpetulty

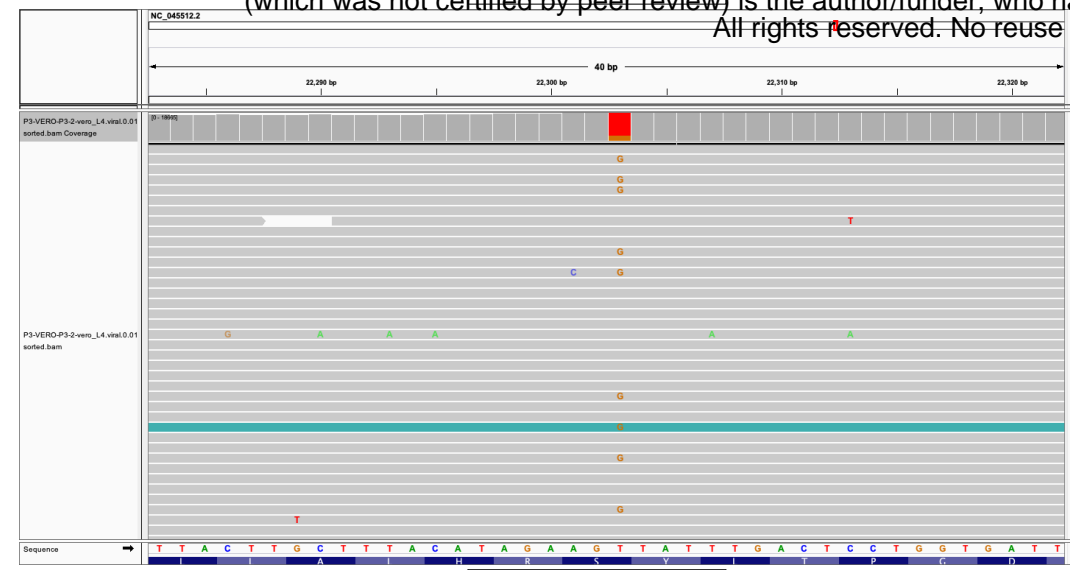

T22303G

ZJU-5

$\mathrm{T}: \mathrm{G}=75 \%: 25 \%$

Ser to Arg
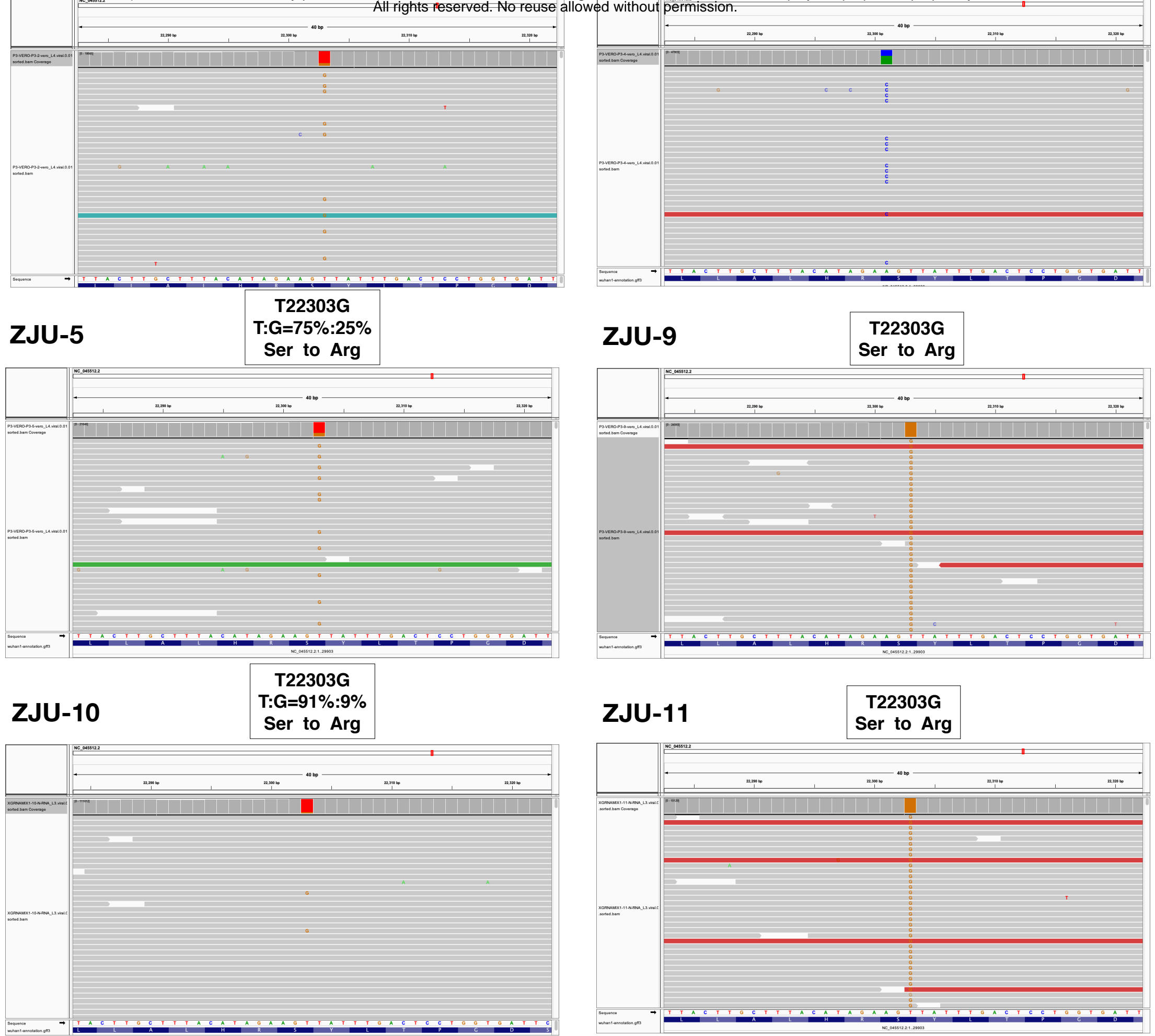

Fig. S1. A summary of the nucleotide mutations that lead to the S247R mutations observed in the 11 patient-derived isolates. Note that some of the mutations are in the form of minor alleles. Images were produced by IGV. 


\section{Brach length - Time}

medRxiv preprint doi: https://doi.org/10.1101/2020.04.14.20060160; this version posted April 23, 2020. The-copyright holder for this preprint (which was not certified by peer review) is the author/funder, who has granted medRxiv a license to display the preprint in perpetuity

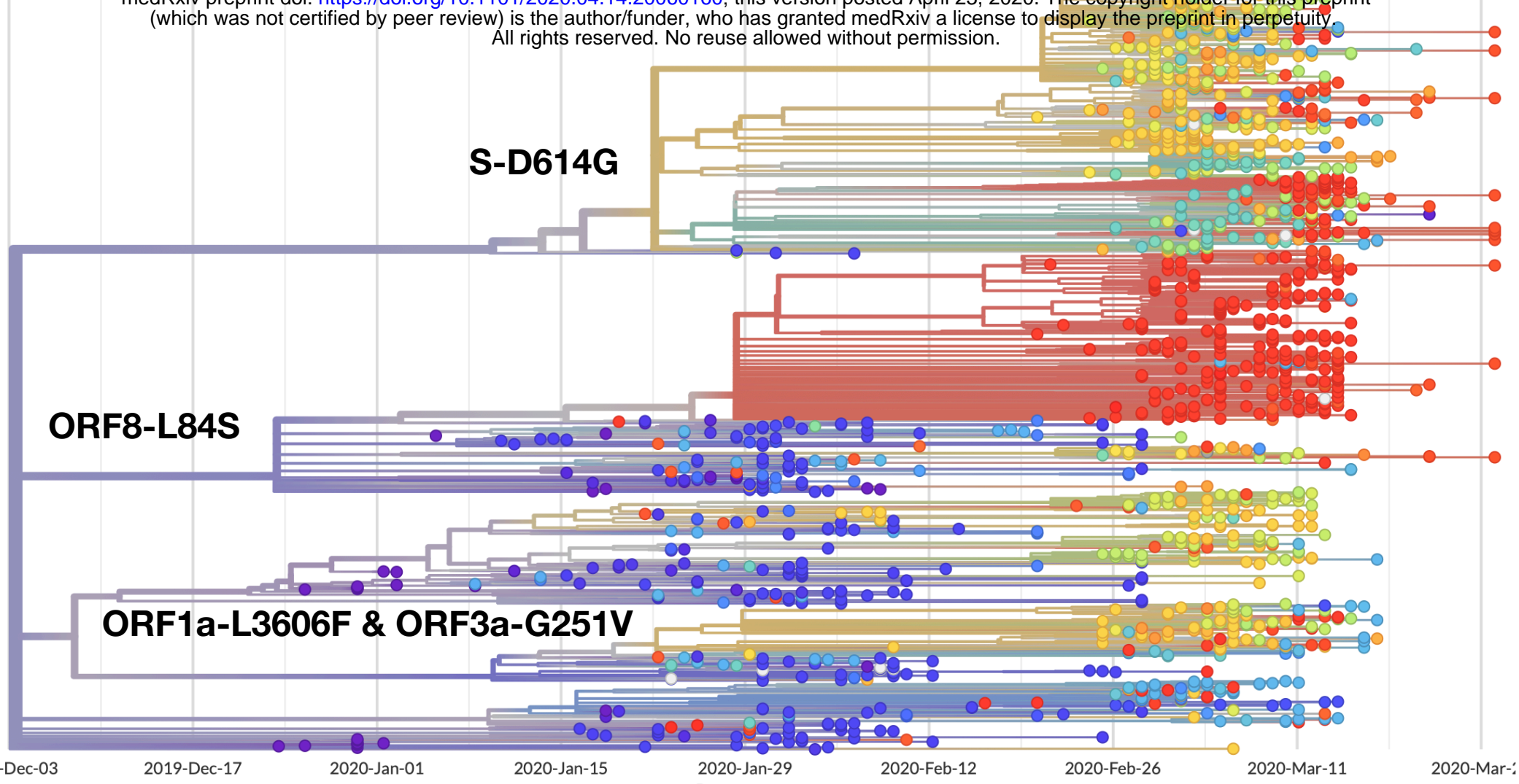

\section{Brach length - Divergence}

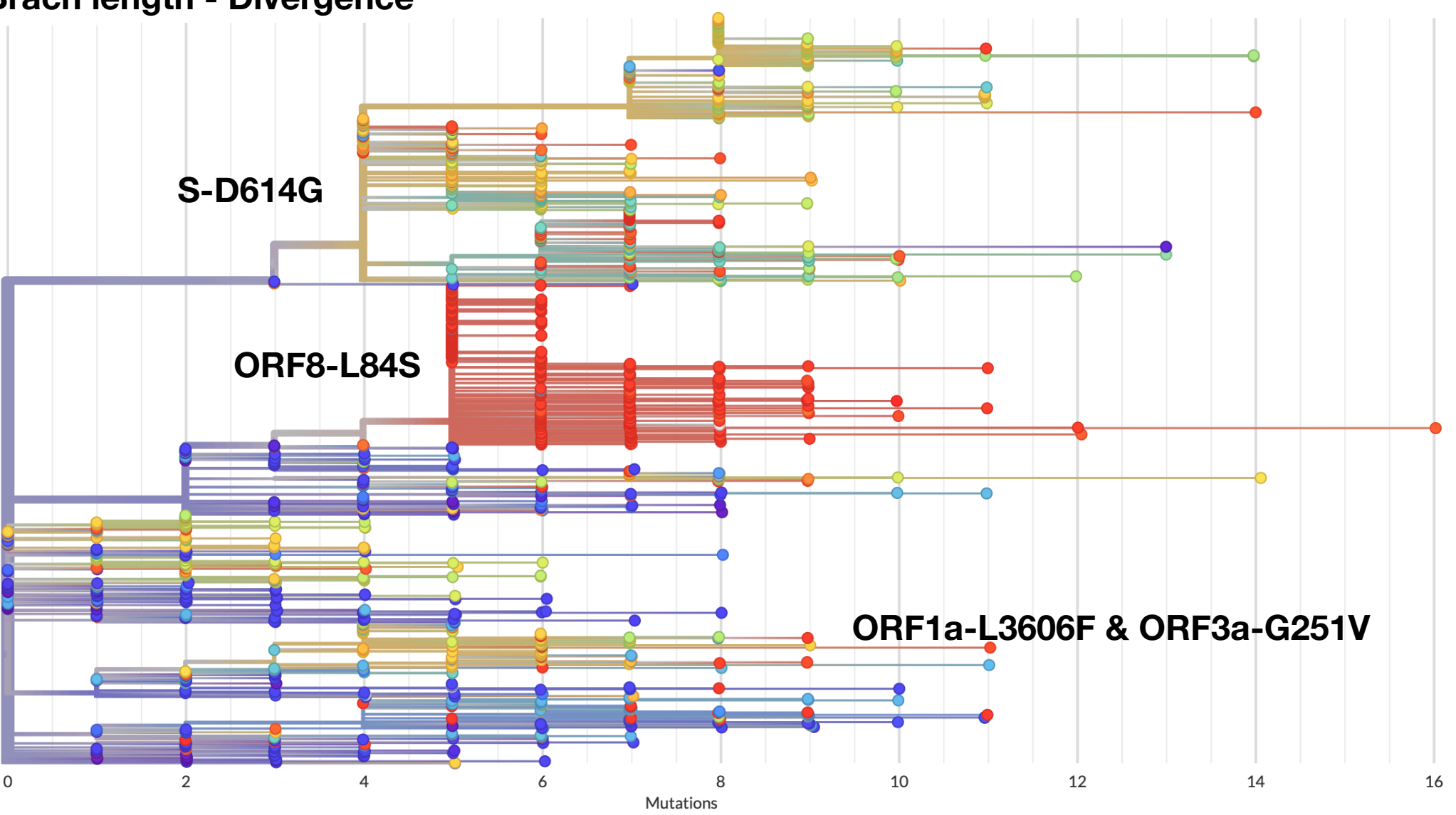

\section{Analyses downloaded on $3 / 28 / 2020$}

Fig. S3. Phylogenetic analyses produced from GISAID using time (top) or number of mutations (bottom) as the branch length.

Note that all three major clusters described in the study are labeled accordingly. The major distinction is that the ORF8-L84S clade is not monophyletic in our more computationally intensive and bootstrapping-supported approach. 
40

medRxiv preprint doi: https://doi.org/10.1101/2020.04.14.20060160; this versioh posted April 23, 2020. The copyright holder for this preprint (which was not certified by peer review) is the author/funder, who has granted medRxiv a license to display the preprint in perpetuity.
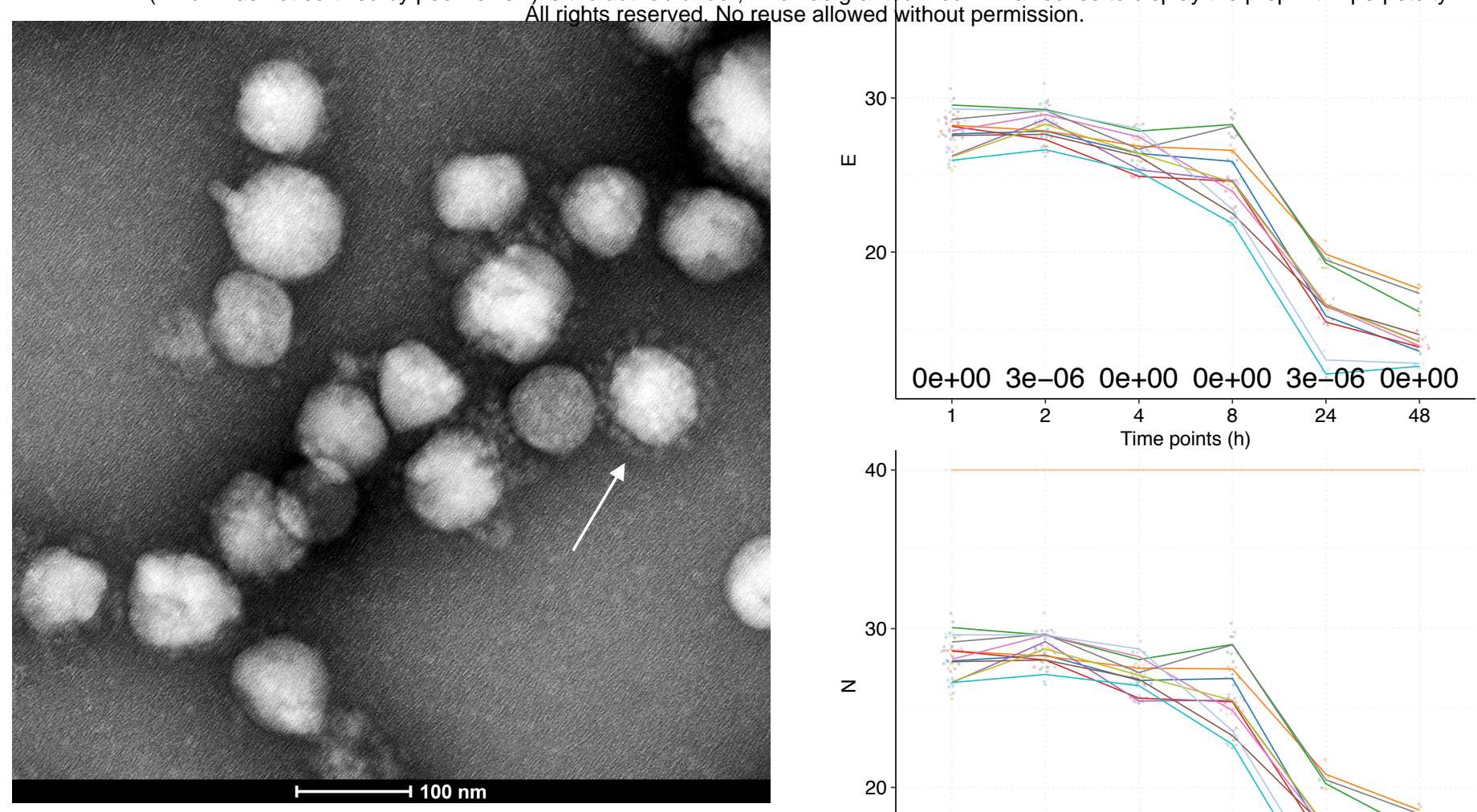

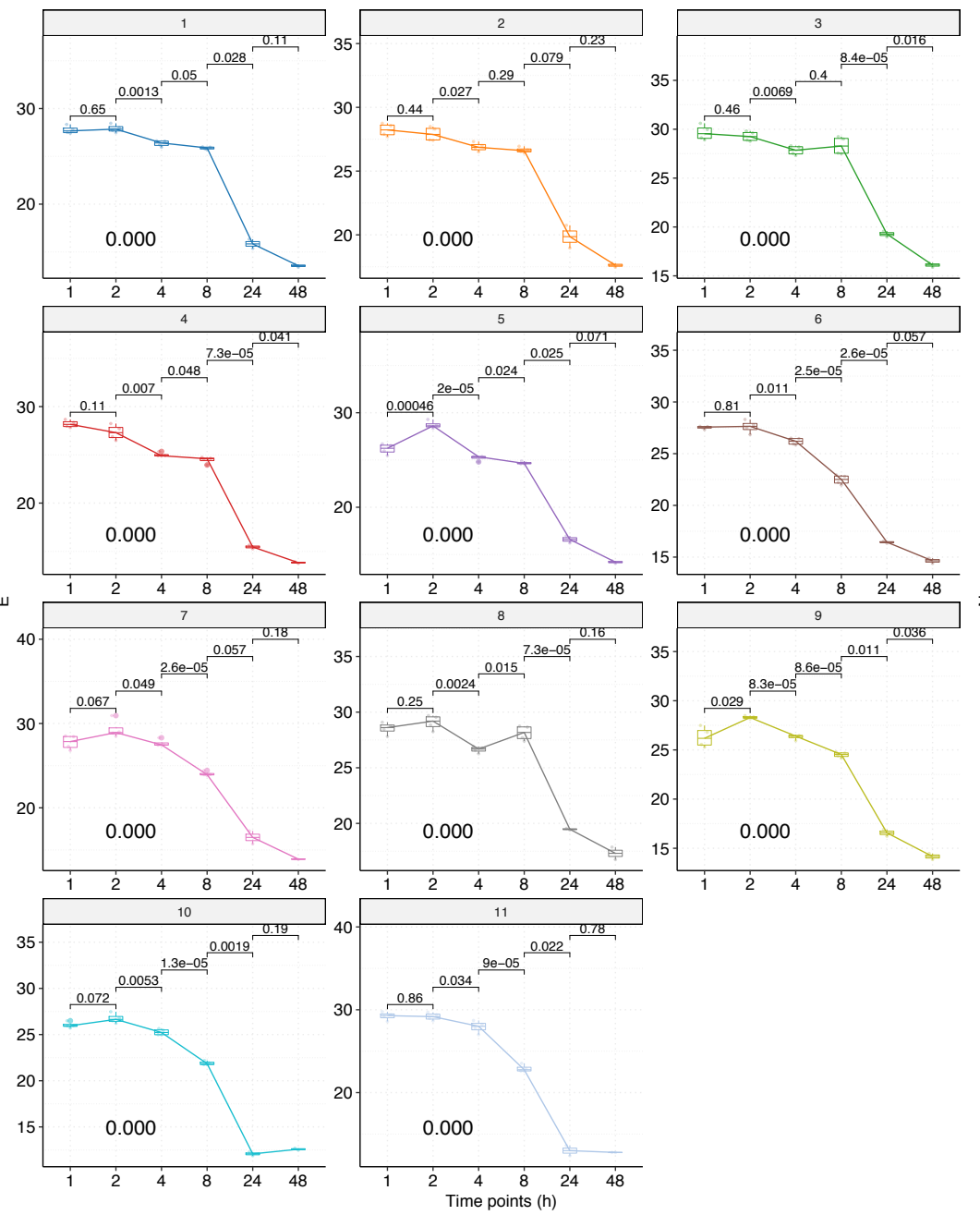

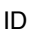

$-1$

$-2$

$-3$

$-5$

$-6$

$-7$

$-9$

-10
-11

$-\mathrm{C}$
C

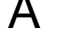

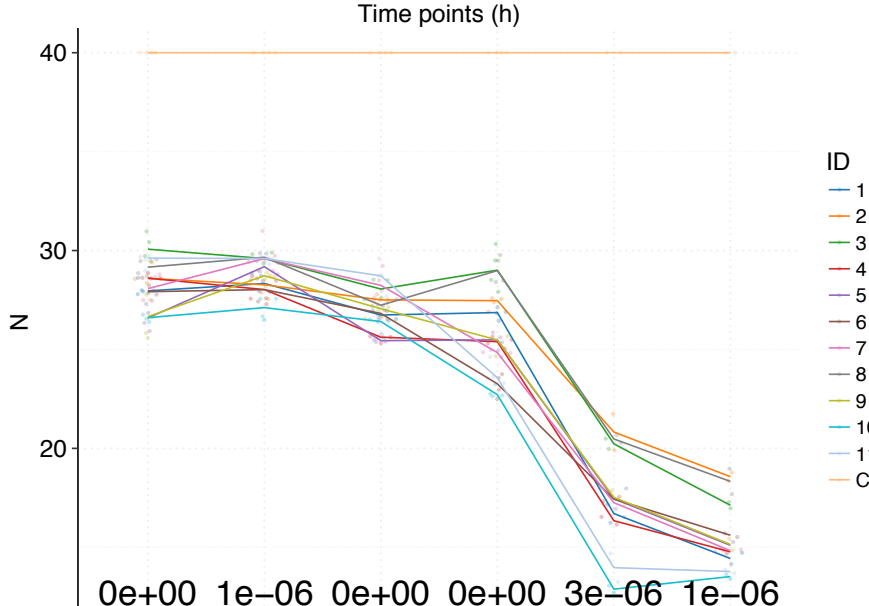

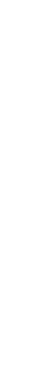

$0 e+00 \quad 1 e-06 \quad 0 e+00 \quad 0 e+00 \quad 3 e-06 \quad 1 e-06$

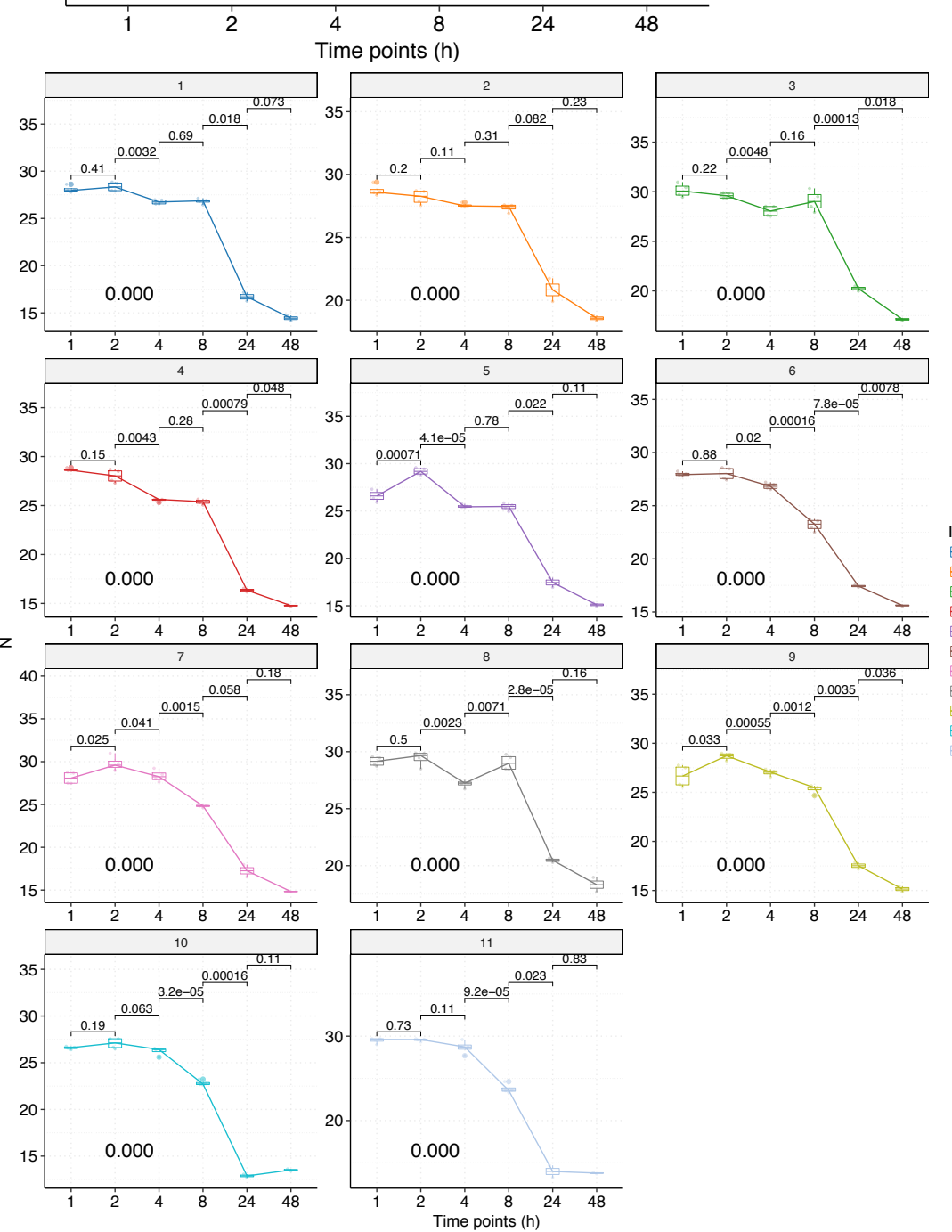


Fig. S4. The characterizations of the 11 viral isolates. (A) A representative TEM picture of the isolated SAR-CoV-2 viral particles, medRxiv preprint doi: https://doi.org/10.1101/2020.04.14.20060160; this version posted April 23, 2020. The copyright holder for this preprint

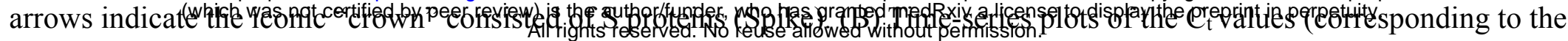
multiplicative inverse of viral load) of the SAR-CoV-2 E gene (top) and N gene (bottom) over the course of infectivity assay. Each viral isolate plus the negative control "C" was color-coded accordingly. P-values were calculated using the ANOVA method to compare the means of all 11 viral isolates at each time point, excluding the negative control "C". (C) Time-series plots of the $\mathrm{C}_{t}$ values of the SAR-CoV-2 E gene (left) and $\mathrm{N}$ gene (right) for each of the 11 patient-derived viral isolates. P-values were calculated between consecutive time points using the t-test and adjusted p-values are shown. 


\section{A}

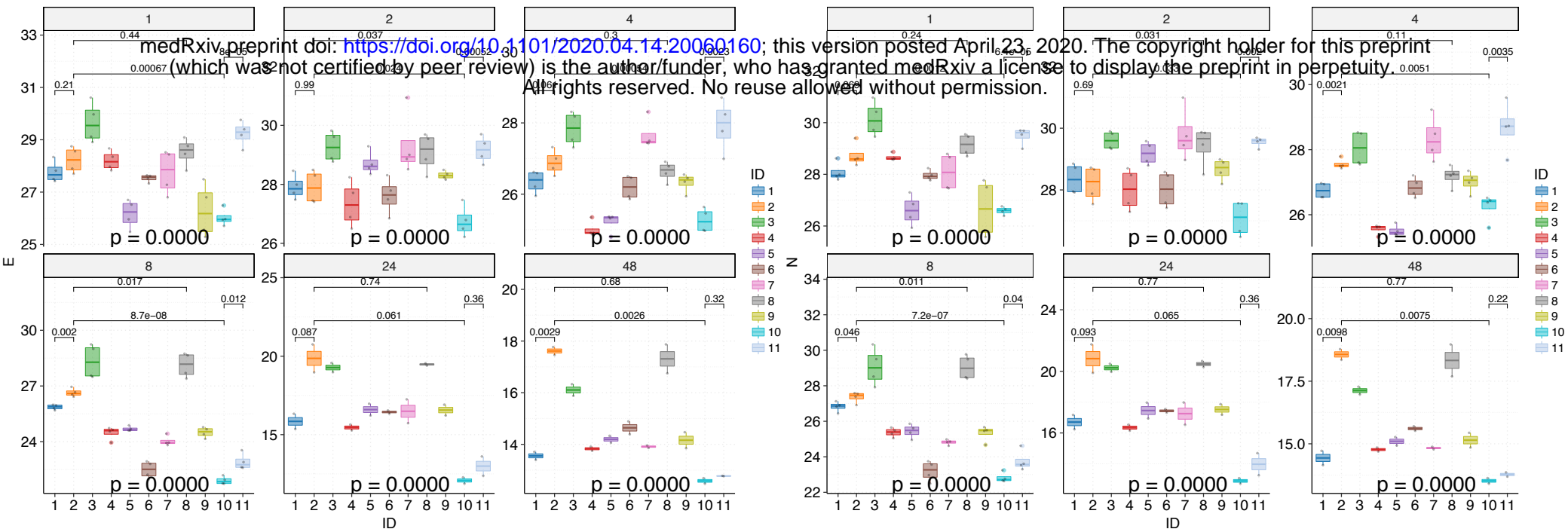

B

$\begin{array}{cr}\text { Viral strain ID } & 48 \mathrm{~h} \text { post } \\ 1 & 1 \\ 2 & 0 \\ 3 & 0 \\ 4 & 0 \\ 5 & 1 \\ 6 & 0 \\ 7 & 1 \\ 8 & 0 \\ 9 & 1.5 \\ 10 & 2 \\ 11 & 1\end{array}$

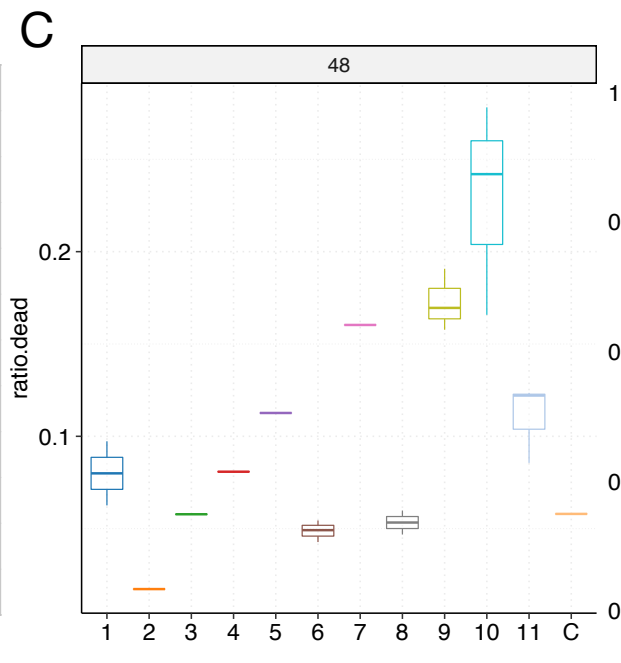

ZJU-1

Control

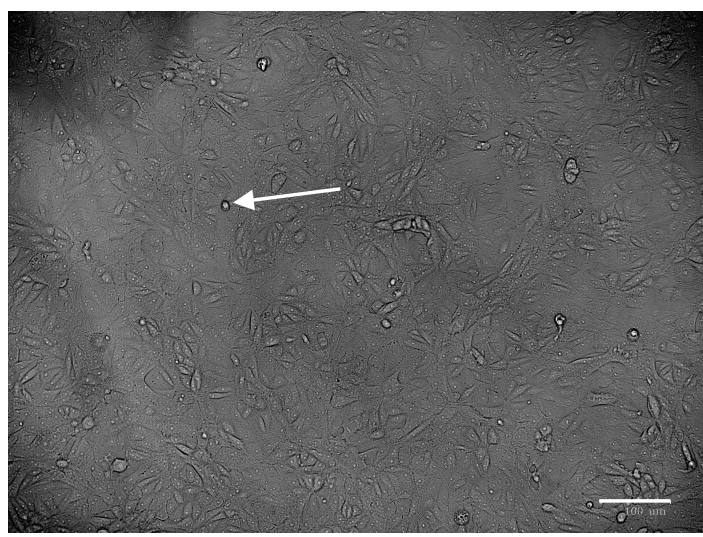

ZJU-8

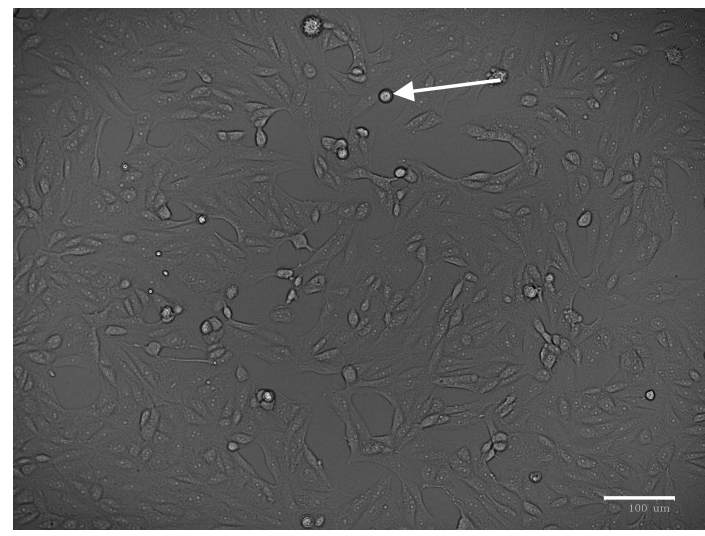

ZJU-10

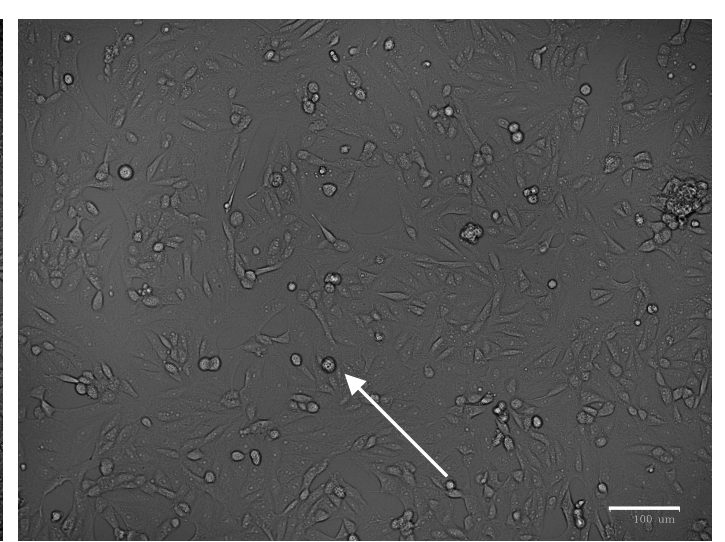

ZJU-2

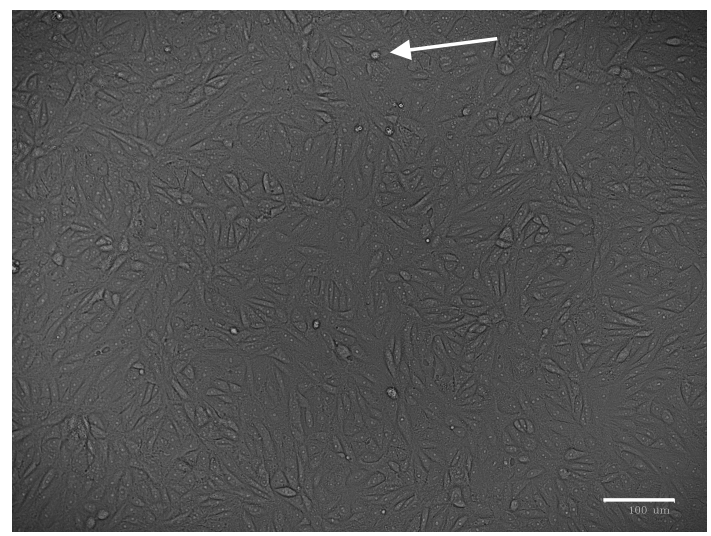

ZJU-11 
Fig. S5. Significant variations were observed in viral load and viral CPE among the 11 patient-derived isolates. (A) Significant

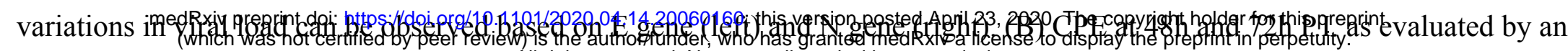
All rights reserved. No reuse allowed without permission.

expert's opinions. (C) CPE at 48h and 72h P.I. evaluated by quantitively calculating the cell death ratio (ratio.dead) for 1-3 images per viral isolate. The results from (B) and (C) are highly correlated (R $>0.89, p<0.001)$. (D) Representative images used for $C P E$ evaluation, arrows indicate cells facing immediate death. Scale bars, $100 \mu \mathrm{m}$. 

Green_monkey/1-805 1 MSGSSWLLLSLVAVTAAQSTIEEQAKTFLDKFNHEAEDLFYQSSLASWNYNTN ITEENVQNMNNAGEKWSAFLKEQSTLAQMYPLQAIQNLTVKLQLQALQQN 103 medRxivpreprint doi: https://doi.org/10.1101/2020.04.14.20060160; this version posted April 23, 2020. The copyright holder for this preprint (which was not certified by peer review) is the author/funder, who has granted medRxiv a license to display the preprint in perpetuity.

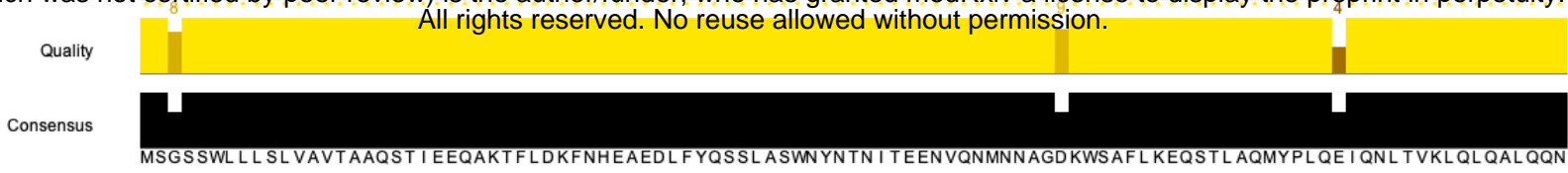

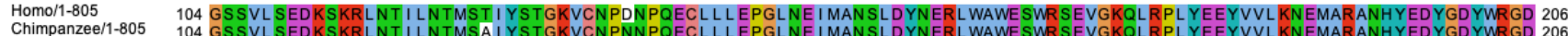

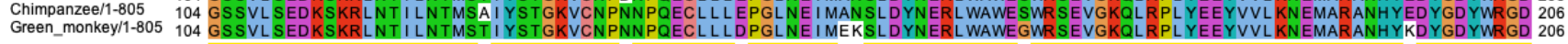

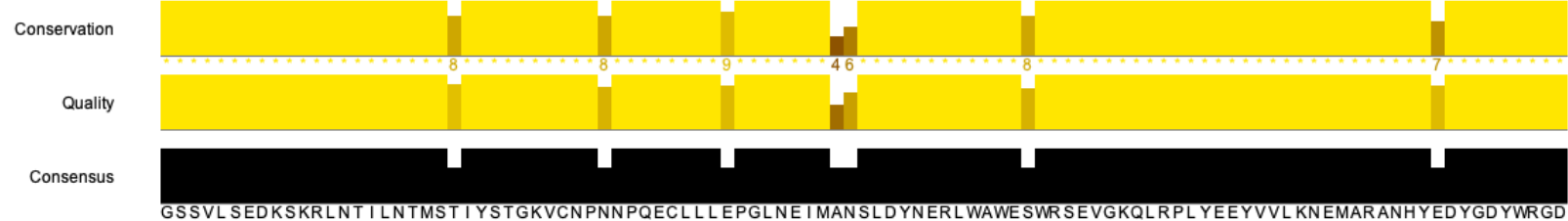

Homo/1-805

Chimpanzee/1-805, 207 Y

GSSL SED KSKRLNT I LNTMST IYSTGKVCNPNN PQECL L LEPGLNE I MANSLDYNERLWAWESWRSEVGKQLRPLYEEYVVL KNEMARANHYEDYGDYWRGD

Conservation

Quality

Consensus

YEVNGVDGYDYSRGQL I EDVEHTFEE I KPL YEHLHAYVRAKL MNAYPSY I SP I GCL PAHL L GDMWGRFWTNL YSL TVPFGQKPN IDVTDAMVDQAWDAQR I FK 309

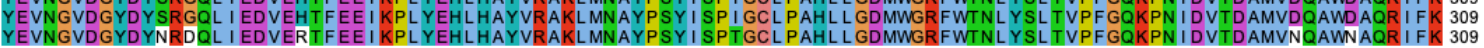

005

Chimpanzee/1-805

Green_monkey/1-805

Conservation

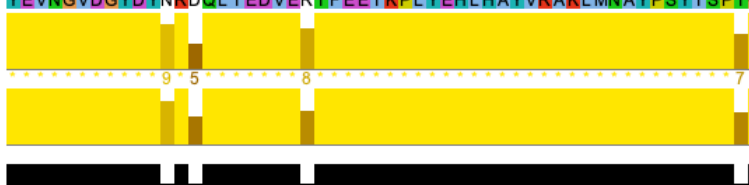

YEVNGVDGYDYSRGQL I EDVEHTFEE I KPL YEHLHAYVRAKLLMNAYPSY I SP I GCLPAHLLGDMWGRFWTNLYSLTVPFGQKPN IDVTDAMVDQAWDAQR IFK

310 EAEKFFVSVGL PNMTQGFWEN SML TDPGNVQKAVCHPTAWDLGKGDFR I LMCTKVTMDDFL TAHHEMGH I QYDMAYAAQPFLLRNGANEGFHEAVGE IMSL SA 412

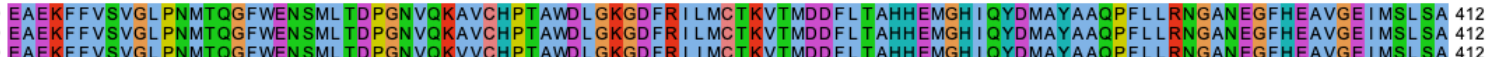

(20)

Quality

Consensus

Homo/1-805

Chimpanzee/1-805

monkey/1-805 413

Conservation

Quality

Consensus

Homo/1-805

Chimpanzee/1-805

Green_monkey/1-805

Conservation

TPKHL KS I GL L SPDFQEDNETE INFLL KQAL TI VGTLPFTYML EKWRWMVF KGE IPKDQWMKKWWEMKRE I VGVVEPVPHDETYCDPASLFHVSNDYSF IRY

ATPHLKS I GLL SPDFQEDNETE I NFLL KQAL T I VGTLPF TYML EKWRWMVFKGEI PKDQWMKKWWEMKRE I VGVVEPVPHDETYCDPASLFHVSNDYSF IRY 515

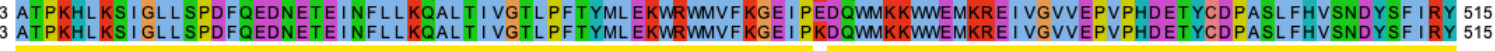

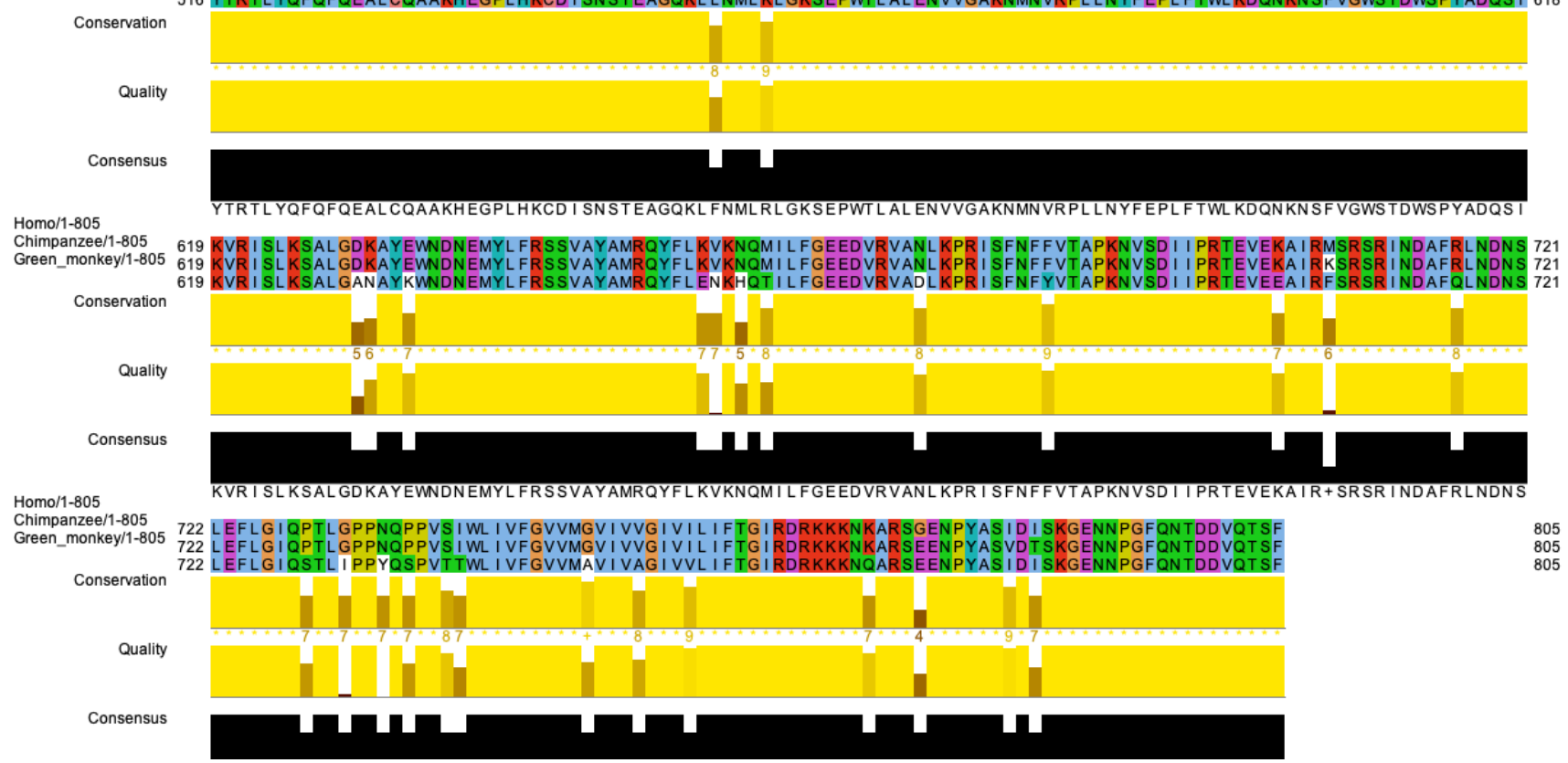

Fig. S6. The alignment of ACE2 protein sequences from human (Homo), Chimpanzee, and green monkey (from which the VeroE6 cell line was derived). Note that overall the ACE2 proteins are highly similar to each other. The alignment and image were produced by Jalview. 


\section{Phylogeny}

Nucleotide at position $28881 \wedge$
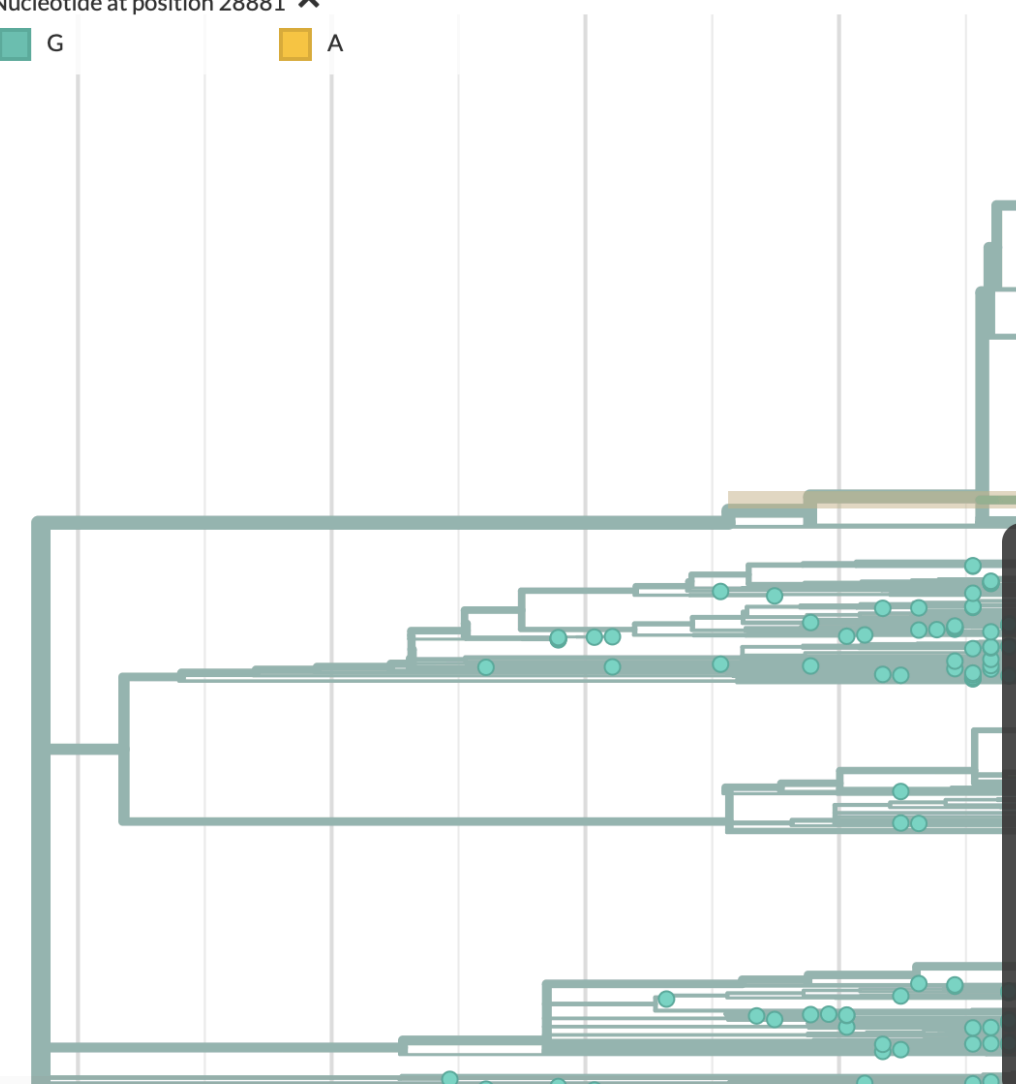

2019-Dec-03

2019-Dec-17

2020-Jan-01

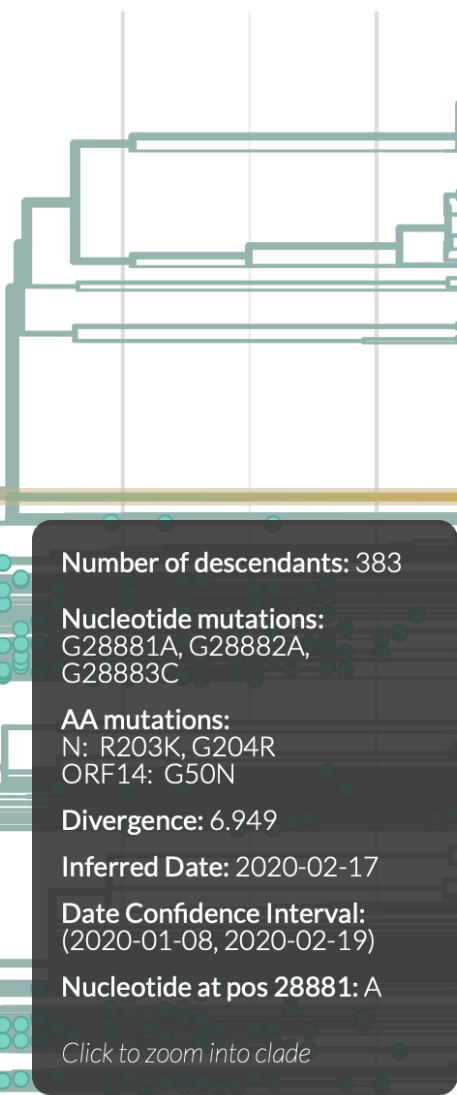

2020-Feb-12

2020-Jan-29

\section{A subclade of the S-D614G group}

\section{Analyses downloaded on 3/31/2020}

Fig. S8. The trinucleotide mutation (G28881A, G28882A, and G28883C) was identified in the GISAID dataset and is the founding mutation for a large cluster of viral isolates within the S-D614G group (European clade). 